In cooperation with the San Antonio Water System

\title{
An Integrated Hydrogeologic and Geophysical Investigation to Characterize the Hydrostratigraphy of the Edwards Aquifer in an Area of Northeastern Bexar County, Texas
}
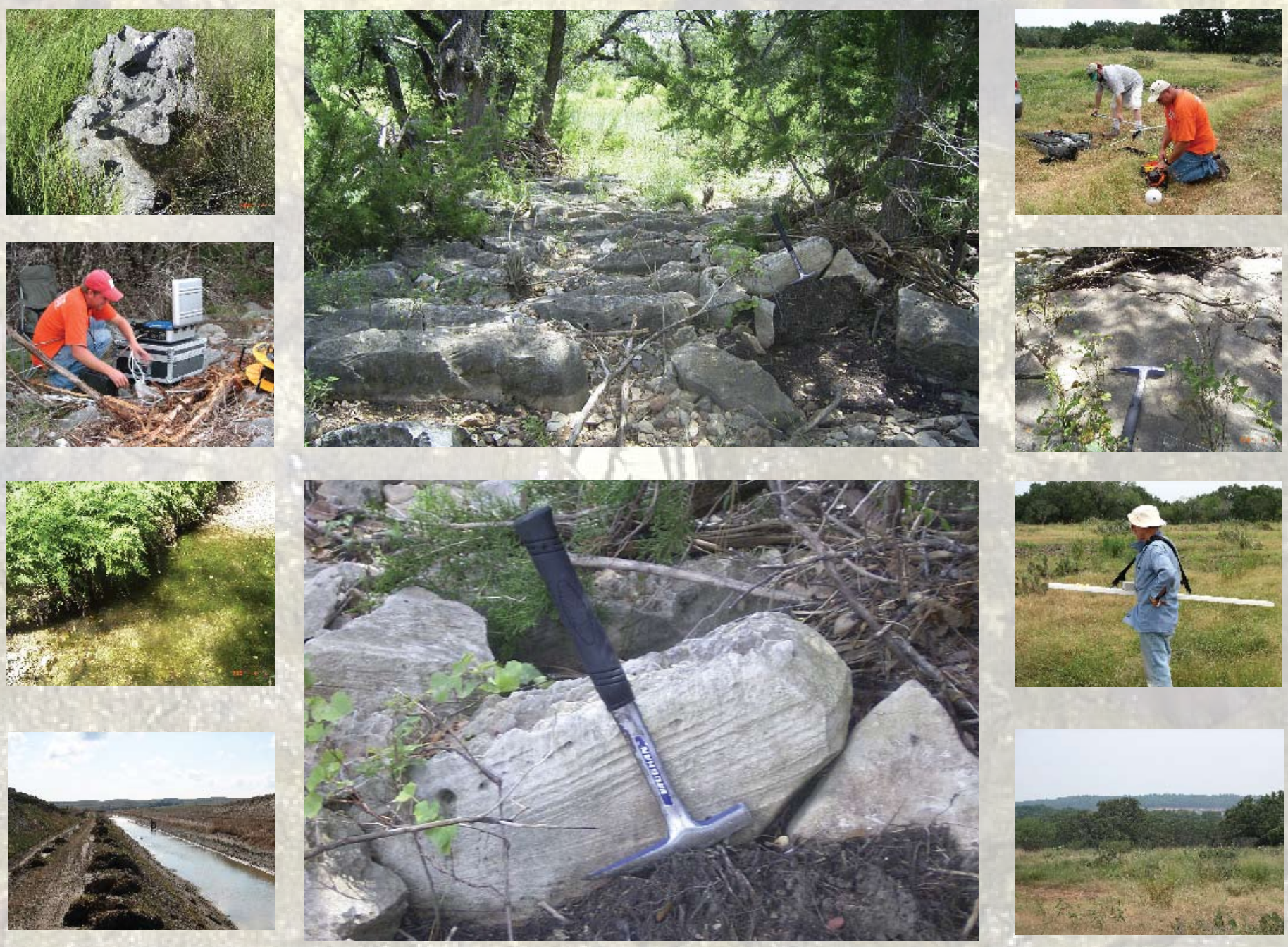

Scientific Investigations Report 2008-5181 

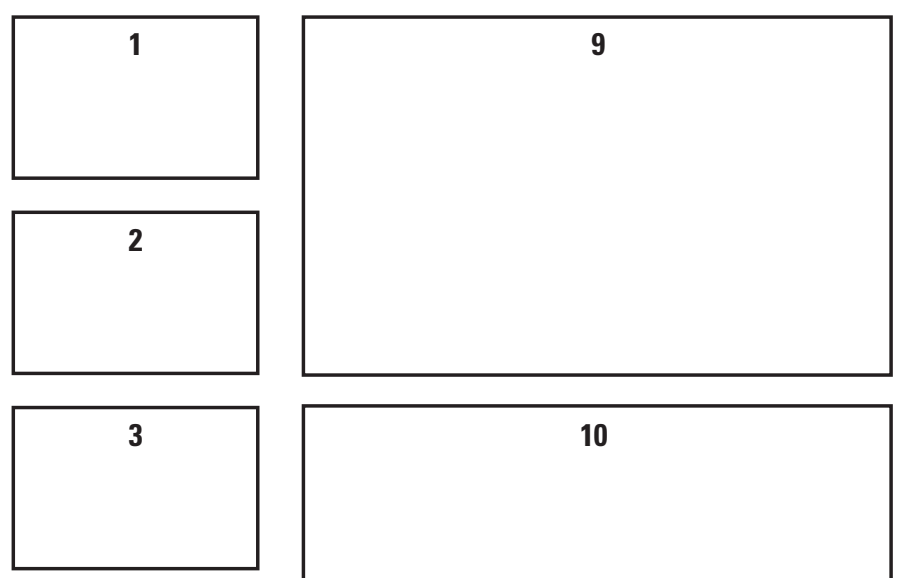

4
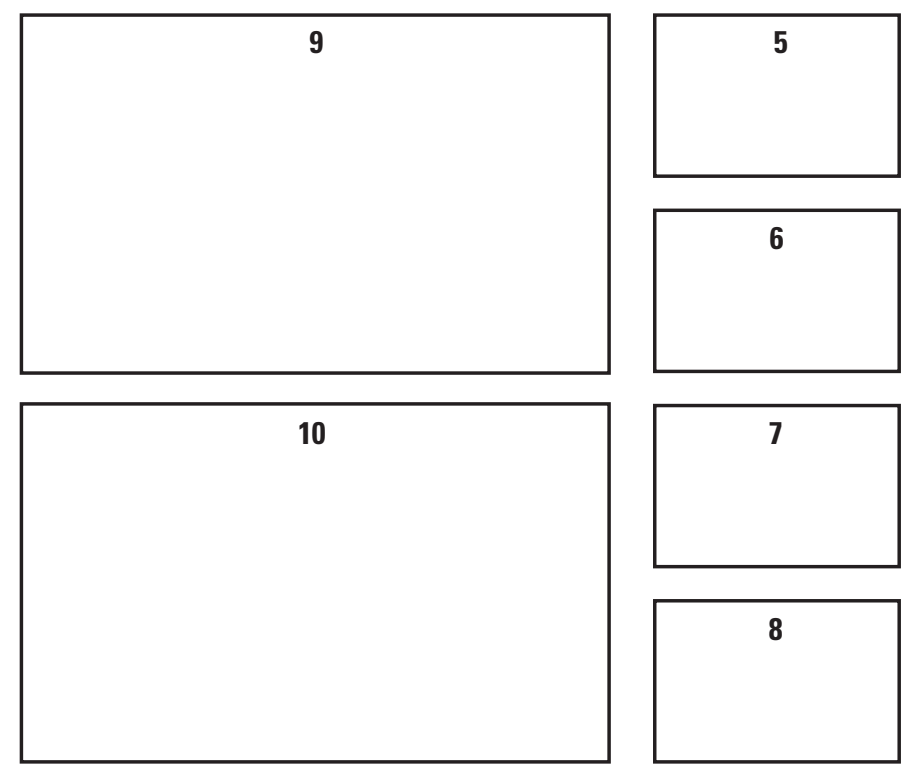

Cover:

(1) Example of vug and channel dissolution porosity in dolomitic member, northwest part of study area.

(2) U.S. Geological Survey technician collecting time-domain electromagnetic data.

(3) Dripping springs near contact of Glen Rose Limestone and basal nodular member, northern part of study area.

(4) View of study area (looking west) after a rain event.

$(\mathbf{5 , 6 )}$ Two views of cross-bedded grainstone member below contact with regional dense member, southern part of study area.

(7) U.S. Geological Survey scientist (foreground) assembling global positioning system equipment.

(8) Dolomitic member of the Edwards aquifer in study area.

(9) U.S. Geological Survey scientist collecting frequency domain electromagnetic data.

and (10) Western view from study area into Comal County. 


\section{An Integrated Hydrogeologic and Geophysical Investigation to Characterize the Hydrostratigraphy of the Edwards Aquifer in an Area of Northeastern Bexar County, Texas}

By Sachin D. Shah, Bruce D. Smith, Allan K. Clark, and Jason D. Payne

In cooperation with the San Antonio Water System

Scientific Investigations Report 2008-5181 


\section{U.S. Department of the Interior DIRK KEMPTHORNE, Secretary}

\section{U.S. Geological Survey \\ Mark D. Myers, Director}

U.S. Geological Survey, Reston, Virginia: 2008

This and other USGS information products are available at http://store.usgs.gov/
U.S. Geological Survey
Box 25286 , Denver Federal Center
Denver, CO 80225
To learn about the USGS and its information products visit http://www.usgs.gov/
1-888-ASK-USGS

Any use of trade, product, or firm names is for descriptive purposes only and does not imply endorsement by the U.S. Government.

Although this report is in the public domain, permission must be secured from the individual copyright owners to reproduce any copyrighted materials contained within this report.

Suggested citation:

Shah, S.D., Smith, B.D, Clark, A.K., and Payne, J.D., 2008, An integrated hydrogeologic and geophysical investigation to characterize the hydrostratigraphy of the Edwards aquifer in an area of northeastern Bexar County, Texas: U.S. Geological Survey Scientific Investigations Report 2008-5181, 26 p. 


\section{Contents}

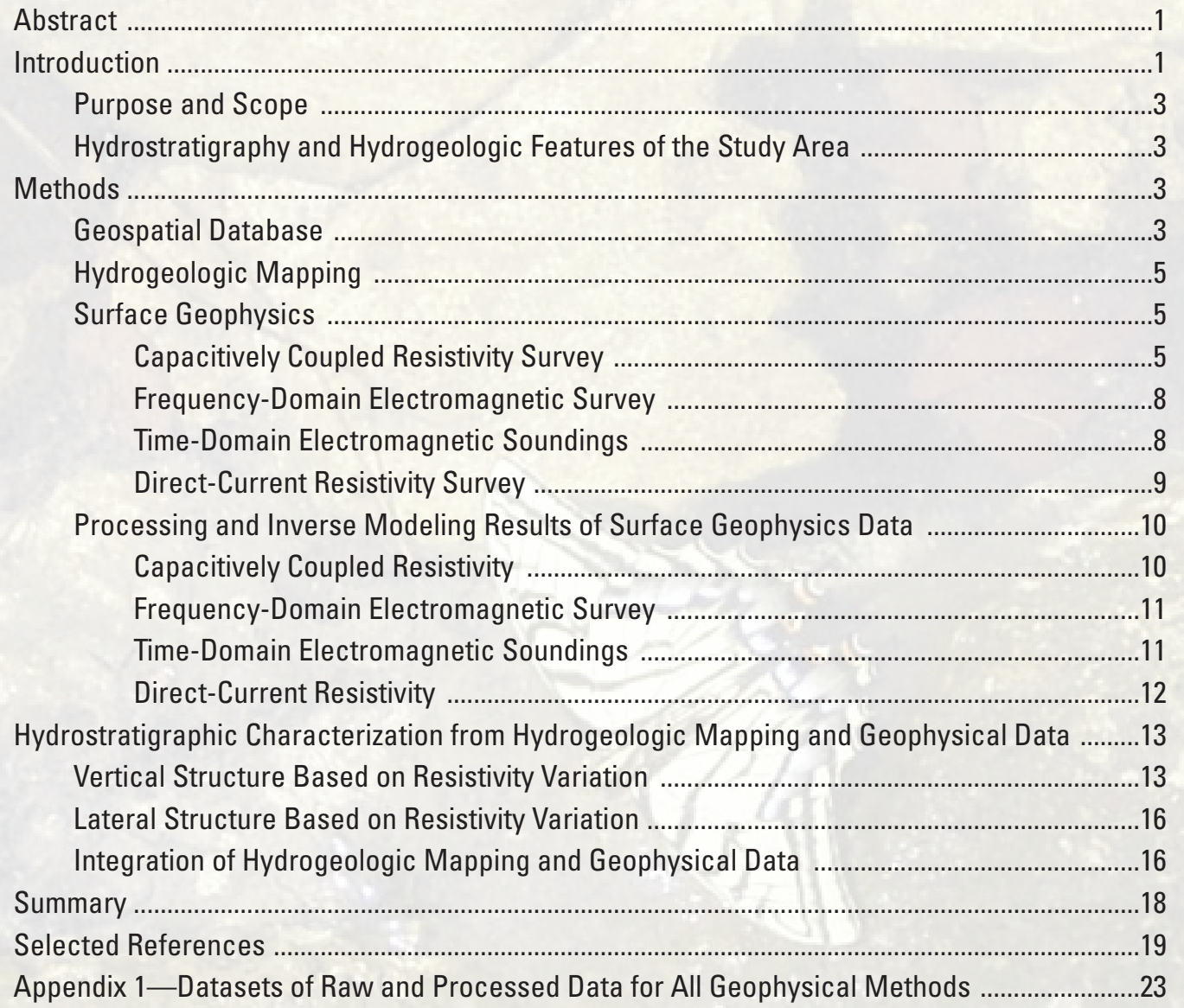

\section{Plate}

1. Previously mapped surface geology, reinterpreted surface geology, and geologic (hydrostratigraphic) section, hydrogeologic and geophysical study area, northeastern Bexar County,Texas

\section{Figures}

1. Map showing location of hydrogeologic and geophysical study area, northeastern Bexar County, Texas

2. Maps showing hydrogeologic and geophysical study area, northeastern Bexar County, Texas, with locations of (A) capacitively coupled resistivity survey lines and two-dimensional direct-current resistivity profiles; and (B) frequencydomain electromagnetic lines and time-domain electromagnetic soundings 
3-6. Photographs showing:

3. OhmMapper TR-5 capacitvely coupled array resistivity system (one transmitter and five receivers) towed by an all-terrain vehicle

4. GEM-2 frequency-domain electromagnetic conductivity meter

5. (A) Receiver coil (loop) for Geonics Protem-57, (B) receiver coil for Geonics Protem-47, and (C) Alpha Geophysics TerraTEM console, which contains the receiver coil

6. (A) IRIS Syscal Pro resistivity system connected to multi-conductor cables and (B) stainless steel electrode take-out built into multi-conductor cable

7. Graphs developed from frequency-domain electromagnetic data showing examples of (A) raw quadrature data collected at a base station with filtered quadrature data superimposed, (B) raw quadrature data collected along a frequency-domain electromagnetic line with filtered quadrature data superimposed, and $(C)$ apparent resistivity along a frequency-domain electromagnetic line calculated from uncalibrated and calibrated (to capacitively coupled resistivity data) quadrature data, hydrogeologic and geophysical study area, northeastern Bexar County, Texas

8. Resistivity-depth section for one capacitively coupled survey line crossing Bat Cave fault, hydrogeologic and geophysical study area, northeastern Bexar County, Texas

9. Resistivity-depth sections for two-dimensional direct-current (2D-DC) resistivity profiles (A) 1 and (B) 2 with time-domain electromagnetic sounding locations, hydrogeologic and geophysical study area, northeastern Bexar County, Texas

10. Map showing hydrogeologic and geophysical study area, northeastern Bexar County, Texas, with (A) near-surface resistivity (after inversion) along capacitively coupled resistivity survey lines and (B) near-surface apparent resistivity along frequency-domain electromagnetic survey lines

\section{Tables}

1. Summary of the lithologic and hydrogeologic properties of the hydrostratigraphic zones of the Glen Rose Limestone and Edwards Group that crop out in the study area, northeastern Bexar County, Texas, from previous studies

2. Location and construction information for monitoring wells, hydrogeologic and geophysical study area, northeastern Bexar County, Texas

3. Capacitively coupled and two-dimensional direct-current resistivity field parameters used for data collection, hydrogeologic and geophysical study area, northeastern Bexar County, Texas

4. Frequency-domain electromagnetic field parameters used during data collection, hydrogeologic and geophysical study area, northeastern Bexar County, Texas.

5. Time-domain electromagnetic sounding field parameters used for data collection, hydrogeologic and geophysical study area, northeastern Bexar County, Texas . .10

6. Hydrogeologic characteristics from mapping and generalized ranges of resistivity for hydrostratigraphic zones of the Edwards aquifer, hydrogeologic and geophysical study area, northeastern Bexar County, Texas 


\section{Conversion Factors}

[SI to Inch/Pound]

\begin{tabular}{lll}
\hline \multicolumn{1}{c}{ Multiply } & By & \multicolumn{1}{c}{ To obtain } \\
\hline & Length & \\
\hline meter $(\mathrm{m})$ & 3.281 & foot $(\mathrm{ft})$ \\
kilometer $(\mathrm{km})$ & 0.6214 & mile $(\mathrm{mi})$ \\
\hline & Area & \\
\hline square kilometer $\left(\mathrm{km}^{2}\right)$ & 0.3861 & square mile $\left(\mathrm{mi}^{2}\right)$ \\
\hline
\end{tabular}

Vertical coordinate information is referenced to North American Vertical Datum of 1988 (NAVD 88).

Horizontal coordinate information is referenced to North American Datum of 1983 (NAD 83).

Altitude, as used in this report, refers to distance above the vertical datum. 
Blank Page 


\title{
An Integrated Hydrogeologic and Geophysical Investigation to Characterize the Hydrostratigraphy of the Edwards Aquifer in an Area of Northeastern Bexar County, Texas
}

\author{
By Sachin D. Shah, Bruce D. Smith, Allan K. Clark, and Jason D. Payne
}

\section{Abstract}

In August 2007, the U.S. Geological Survey, in cooperation with the San Antonio Water System, did a hydrogeologic and geophysical investigation to characterize the hydrostratigraphy (hydrostratigraphic zones) and also the hydrogeologic features (karst features such as sinkholes and caves) of the Edwards aquifer in a 16-square-kilometer area of northeastern Bexar County, Texas, undergoing urban development. Existing hydrostratigraphic information, enhanced by local-scale geologic mapping in the area, and surface geophysics were used to associate ranges of electrical resistivities obtained from capacitively coupled (CC) resistivity surveys, frequencydomain electromagnetic (FDEM) surveys, time-domain electromagnetic (TDEM) soundings, and two-dimensional direct-current (2D-DC) resistivity surveys with each of seven hydrostratigraphic zones (equivalent to members of the Kainer and Person Formations) of the Edwards aquifer. The principal finding of this investigation is the relation between electrical resistivity and the contacts between the hydrostratigraphic zones of the Edwards aquifer and the underlying Trinity aquifer in the area. In general, the TDEM data indicate a two-layer model in which an electrical conductor underlies an electrical resistor, which is consistent with the Trinity aquifer (conductor) underlying the Edwards aquifer (resistor). TDEM data also show the plane of Bat Cave fault, a well-known fault in the area, to be associated with a local, nearly vertical zone of low resistivity that provides evidence, although not definitive, for Bat Cave fault functioning as a flow barrier, at least locally. In general, the CC resistivity, FDEM survey, and 2D-DC resistivity survey data show a sharp electrical contrast from north to south, changing from high resistivity to low resistivity across Bat Cave fault as well as possible karst features in the study area. Interpreted karst features that show relatively low resistivity within a relatively high-resistivity area likely are attributable to clay or soil filling a sinkhole. In general, faults are inferred where lithologic incongruity indicates possible displacement. Along most inferred faults, displacement was not sufficient to place different members of the Kainer or Person Formations (hydrostratigraphic zones) adjacent across the inferred fault plane. In general, the Kainer Formation (hydrostratigraphic zones V through VIII) has a higher resistivity than the Person Formation (hydrostratigraphic zones II through IV). Although resistivity variations from the $\mathrm{CC}$ resistivity, FDEM, and 2D-DC resistivity surveys, with mapping information, were sufficient to allow surface mapping of the lateral extent of hydrostratigraphic zones in places, resistivity variations from TDEM data were not sufficient to allow vertical delineation of hydrostratigraphic zones; however, the Edwards aquifer-Trinity aquifer contact could be identified from the TDEM data.

\section{Introduction}

The Edwards aquifer is a productive karst (dissolutionmodified) aquifer in south-central Texas. The fractured and faulted, predominately limestone aquifer is the primary source of public water supply for Bexar County, where San Antonio is located, and supplies large quantities of water to agriculture, industry, and major springs in adjacent Comal and Hays Counties. Major springs flowing from the aquifer support recreational and business activities and provide water to downstream users. Recharge to the Edwards aquifer is from streamflow loss and direct infiltration of rainfall in the recharge zone, which is essentially the outcrop of the aquifer along its northwestern margin. Also, cross-formational flow into the Edwards aquifer from the laterally adjacent (to the recharge zone) and underlying Trinity aquifer probably occurs (Stein and Ozuna, 1995).

Presently (2007), a 16-square-kilometer $\left(\mathrm{km}^{2}\right)$ area of mainly rangeland in Bexar County northeast of San Antonio (fig. 1) is undergoing urban development. Residential and commercial development in much of the recharge zone in Bexar County is increasing. The aquifer could become contaminated by leakage of hazardous materials, or runoff 


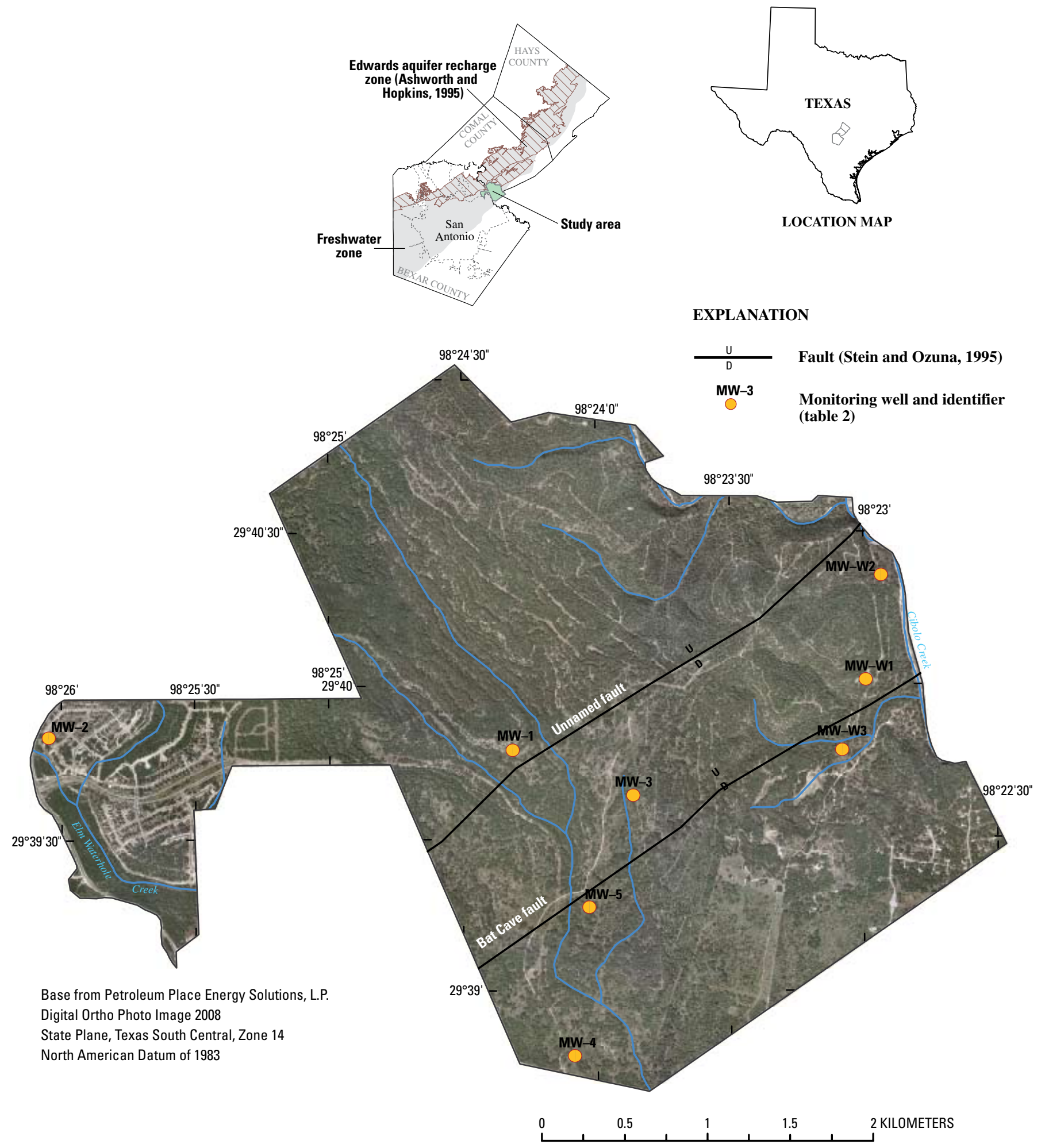

Figure 1. Location of hydrogeologic and geophysical study area, northeastern Bexar County, Texas. 
containing fertilizers, pesticides, herbicides, automobile fluids, or other commonly used chemicals from the developing urban areas that surround, or are built on, the recharge zone (Buszka, 1987; Kipp and others, 1993).

In August 2007, the U.S. Geological Survey (USGS), in cooperation with the San Antonio Water System, did a hydrogeologic and geophysical investigation to characterize the hydrostratigraphy (hydrostratigraphic zones) and also the hydrogeologic features (karst features such as sinkholes and caves) of the aquifer in the area of northeastern Bexar County undergoing development (study area). Hydrostratigraphic zones (Maclay, 1995) are subdivisions of the Edwards aquifer with distinct lithology, porosity, permeability, and hydrogeologic features. Knowledge of the hydrostratigraphy (and hydrogeologic features) can lead to better understanding of the potential for vertical movement of water into the aquifer and lateral flow in the aquifer, and thus provide decision support for placement of monitoring wells for detecting contamination associated with urbanization.

\section{Purpose and Scope}

This report presents the results of an integrated hydrogeologic and geophysical investigation to characterize the hydrostratigraphy of the Edwards aquifer in an area of northeastern Bexar County, Texas. Existing hydrostratigraphic information, enhanced by local-scale geologic mapping in the study area, and surface geophysics were used to associate ranges of electrical resistivities with each of seven hydrostratigraphic zones of the Edwards aquifer. Variations in electrical resistivities were used in conjunction with mapped data to identify, to the extent possible, the vertical and lateral extent of the hydrostratigraphic zones at selected sites in the study area. Four surface geophysical instruments (tools) were used to collect data. The tools were selected to provide complementary data and gain the most useful information regarding variations in electrical resistivity. The theory and attributes of each geophysical tool used are briefly described. Selected resistivity data collected are shown in two-dimensional sections and compared to mapped surface geology. The report explains how the resistivity data were interpreted relative to existing hydrostratigraphic information and mapped data to identify hydrostratigraphic zones and update previously mapped surface geology in the study area. Data were not collected over the entire study area, and thus the report is more of a reconnaissance-level assessment rather than a comprehensive assessment of the study area.

\section{Hydrostratigraphy and Hydrogeologic Features of the Study Area}

The near-surface, karstic rocks in the study area consist of Lower Cretaceous, predominately limestone formations. From oldest to youngest, the major units are the Glen Rose Limestone and Kainer and Person Formations of the Edwards
Group (table 1). This report focuses on the Kainer and Person Formations (rocks of the Edwards aquifer), although geophysical data also were collected in the Glen Rose Limestone (rocks of the Trinity aquifer).

In this report, hydrostratigraphy refers to seven hydrostratigraphic zones of the Edwards aquifer (table 1). The term "hydrostratigraphic zone" was first used by Maclay (1995) to refer to eight subdivisions of the Edwards aquifer previously identified by Maclay and Small (1976). (Hydrostratigraphic zone I of Maclay [1995] is missing in the study area.) Maclay and Small (1976) identified the zones on the basis of test-hole cores and borehole geophysical logs. The cores and logs indicated distinct lithology, fracture characteristics, and porosity of the eight aquifer subdivisions, five of which are hydrogeologic equivalents or combinations of the seven informal members of the Kainer and Person Formations described by Rose (1972). Stein and Ozuna (1995) mapped the hydrostratigraphic zones of the Edwards aquifer recharge zone in Bexar County, although in that report the zones are referred to as hydrogeologic subdivisions. The Stein and Ozuna (1995, pl. 1) geologic map indicating hydrogeologic subdivisions was used as the basis for geologic mapping in this study, and that map was revised for this report.

The permeability of the Edwards aquifer is the result, in part, from fracture and dissolution porosity (Maclay and Small, 1976). Lithology, diagenesis, and karstification account for much of the effective porosity and permeability in the Edwards aquifer. Hydrogeologic features such as sinkholes and caves associated with these processes can greatly enhance the effective porosity and permeability of the aquifer. The primary controlling factor on cavern development in the Edwards aquifer appears to be fractures (Veni, 1988). Fracturing perpendicular to primary fault trends appears to have contributed to cave formation (Clark and Journey, 2006). Table 1 indicates the hydrogeologic function, which in part depends on hydrogeologic features, and associated cavern development of each hydrostratigraphic zone of the Edwards aquifer and the relative permeability.

Faulting can create pathways for water to move downward into the aquifer, and faults can present barriers to lateral flow in the aquifer. An important subregional fault in the study area is Bat Cave fault (George, 1952) (fig. 1), which trends southwest to northeast.

\section{Methods}

\section{Geospatial Database}

A geospatial database was developed to consolidate geophysical and geologic data collected for this report, data from aerial photographs, and data from previous reports. The geospatial database was developed using Oasis montaj (Geosoft Inc., 2007). Oasis montaj is a type of geographic information 
Table 1. Summary of the lithologic and hydrogeologic properties of the hydrostratigraphic zones of the Glen Rose Limestone and Edwards Group that crop out in the study area, northeastern Bexar County, Texas, from previous studies.

[Edwards Group, Kainer, and Person Formations from Rose (1972); Edwards Group members modified from Rose (1972); upper member, Glen Rose Limestone from Barker and Ardis (1996); hydrostratigraphic zones (Edwards aquifer) from Maclay (1995); hydrostratigraphic zone (Trinity aquifer) from Clark (2003); thicknesses and lithologies (Edwards Group) from Stein and Ozuna (1995); thickness and lithology (upper member, Glen Rose Limestone) from Clark (2003); relative permeability modified from Stein and Ozuna (1995), Maclay (1995), and Clark (2003); --, not available or not applicable]

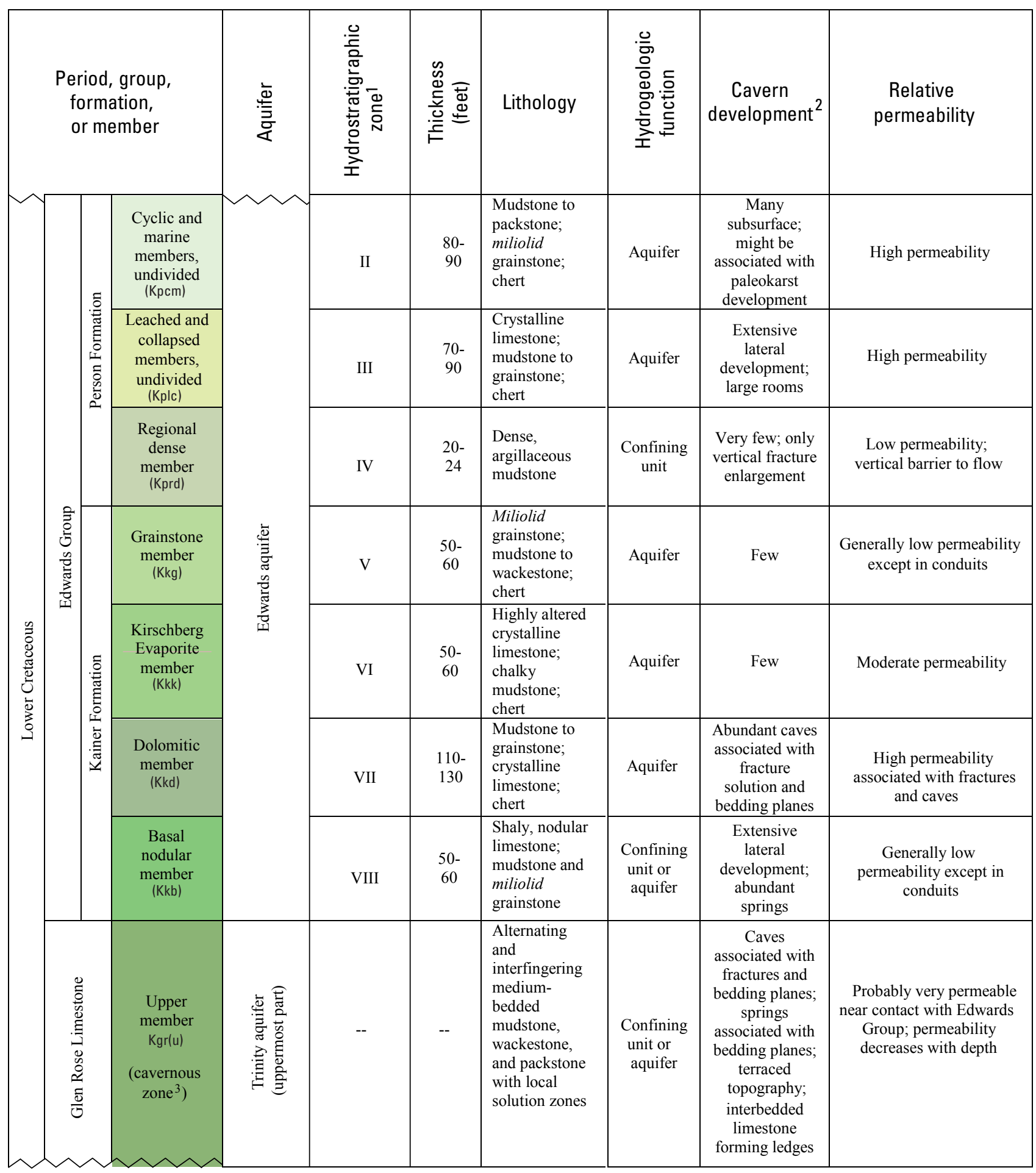

\footnotetext{
${ }^{1}$ Hydrostratigraphic zone I of Maclay (1995) is the Georgetown Formation, the uppermost unit of the Edwards aquifer, which is missing in the study area.

${ }^{2}$ From hydrogeologic mapping for this report.

${ }^{3}$ George Veni, George Veni \& Associates, written commun., 2000.
} 
system (GIS) software used to create, manage, and visualize the database. Oasis montaj was used to evaluate the geophysical data collected for this report along with borehole geologic and geophysical log data from eight wells previously drilled in the study area (table 2). Raw geophysical data that were collected also were converted to an American Standard Code for Information Interchange (ASCII) format and archived in the geospatial database. Locations of sinkholes, caverns, and other karst features also were entered into the geospatial database. The geospatial database was used during fieldwork to produce lithologic and resistivity sections and to do various types of spatial analyses that were helpful in understanding and visualizing the subsurface.

\section{Hydrogeologic Mapping}

Surface geologic units were visually identified from outcrops and karst features, and with the aid of geologic information from previous reports, primarily Stein and Ozuna (1995), and also Clark (2003) and Hanson and Small (1995). Lithologic descriptions from Clark (2003) and Stein and Ozuna (1995) (table 1) are based on Dunham's (1962) classification of carbonate rocks according to texture and whether the rock is mud-supported (mudstone and wackestone) or grain-supported (packstone and grainstone). Distinctive marker beds were identified in the field and used to correlate hydrostratigraphic zones in the study area. Thicknesses of the various formations and members were determined on the basis of field observations, geophysical logs, and data from the aforementioned reports. The hydrogeologic mapping data were processed using GIS technology to produce a map of surface geology showing members of the Kainer and Person Formations equivalent to hydrostratigraphic zones (and faults) that updates the Stein and Ozuna (1995, pl. 1) map of surface geology in which members of the Kainer and Person Formations were called hydrogeologic subdivisions. Fault traces identified in the field were characterized by the orientation, dip of formational bedding, and observed lithologic incongruities.

\section{Surface Geophysics}

Four surface geophysical methods were used to refine and characterize the hydrostratigraphy and surface geologic contacts. Multiple methods were used to achieve a more comprehensive analysis of the subsurface. The combination of methods made it possible to accurately estimate the thickness, extent, and lateral variation in the resistivity of the subsurface, which then could be used to correlate geophysical features or anomalies and hydrostratigraphic units. About 17 kilometers $(\mathrm{km})$ of continuous capacitively coupled $(\mathrm{CC})$ resistivity survey lines, $30 \mathrm{~km}$ of continuous frequency-domain electromagnetic (FDEM) survey lines, 40 time-domain electromagnetic (TDEM) soundings ( 29 were used), and two east-west-trending 480-meter (m)-long two-dimensional direct-current (2D-DC) resistivity survey profiles were collected at the site (fig. 2). The TDEM soundings provide data for determining vertical resistivity variation, and the $\mathrm{CC}$ resistivity, FDEM, and 2D-DC resistivity surveys provide data for determining lateral resistivity variation.

The electrical properties of soils and rocks are determined by water content, porosity, clay content, and conductivity (reciprocal of electrical resistivity) of the pore water (Lucius and others, 2007). Typically, the resistivity of water has a large effect on the bulk resistivity of the subsurface. The geophysical methods of this study can be used to determine the depth and lateral extent of clay, sand, and gravel, along with the depth to water and depth to bedrock. Interpretations from these measurements can be used to image the distribution of physical properties in the subsurface. Descriptions of various resistivity methods, as well as tables of the electrical properties of earth materials, are in Zohdy and others (1974), Fitterman and Labson (2005), and Lucius and others (2007).

The tools used for this report measured the voltage response of the earth from a current applied to the earth through current injection or electromagnetic induction. The raw data collected by these instruments are filtered statistically to remove poor quality (noisy) data and are then used to calculate apparent resistivity of the subsurface. Apparent resistivity represents the resistivity of a completely uniform (homogenous and isotropic) earth material (Keller and Frischknecht, 1966). To determine the resistivity of a non-uniform earth material that would have the same voltage response for any applied current, inverse modeling software is used. The application of inverse modeling methods used for this report is described in Fitterman and Labson (2005) and Kress and others (2006).

\section{Capacitively Coupled Resistivity Survey}

The Geometrics OhmMapper (Geometrics Inc., 2007) TR-5 (fig. 3) was used to measure the resistivity of nearsurface rocks in the study area. The OhmMapper TR-5 is a capacitively coupled, towed-array resistivity system comprising one transmitter and a combination of one to five receivers. Dipole antennas are required to make a $\mathrm{CC}$ resistivity measurement. A dipole antenna constitutes two wires, one on each side of the transmitter or receiver, that induce (through capacitance) or respond to an alternating current at a fixed frequency. The response measured by the receiver is the resultant voltage. Resistance is computed using Ohm's law and is converted to apparent resistivity by applying the appropriate geometric correction factor (Zohdy and others, 1974).

The depth of investigation can be altered by increasing the separation distance between the transmitter and the receiver (dipole separation factor), similar to the changing of electrode spacing in more traditional resistivity measurements. To increase the depth of penetration and vertical resolution of apparent resistivity, several configurations of antenna lengths and antenna separation distances were evalu- 


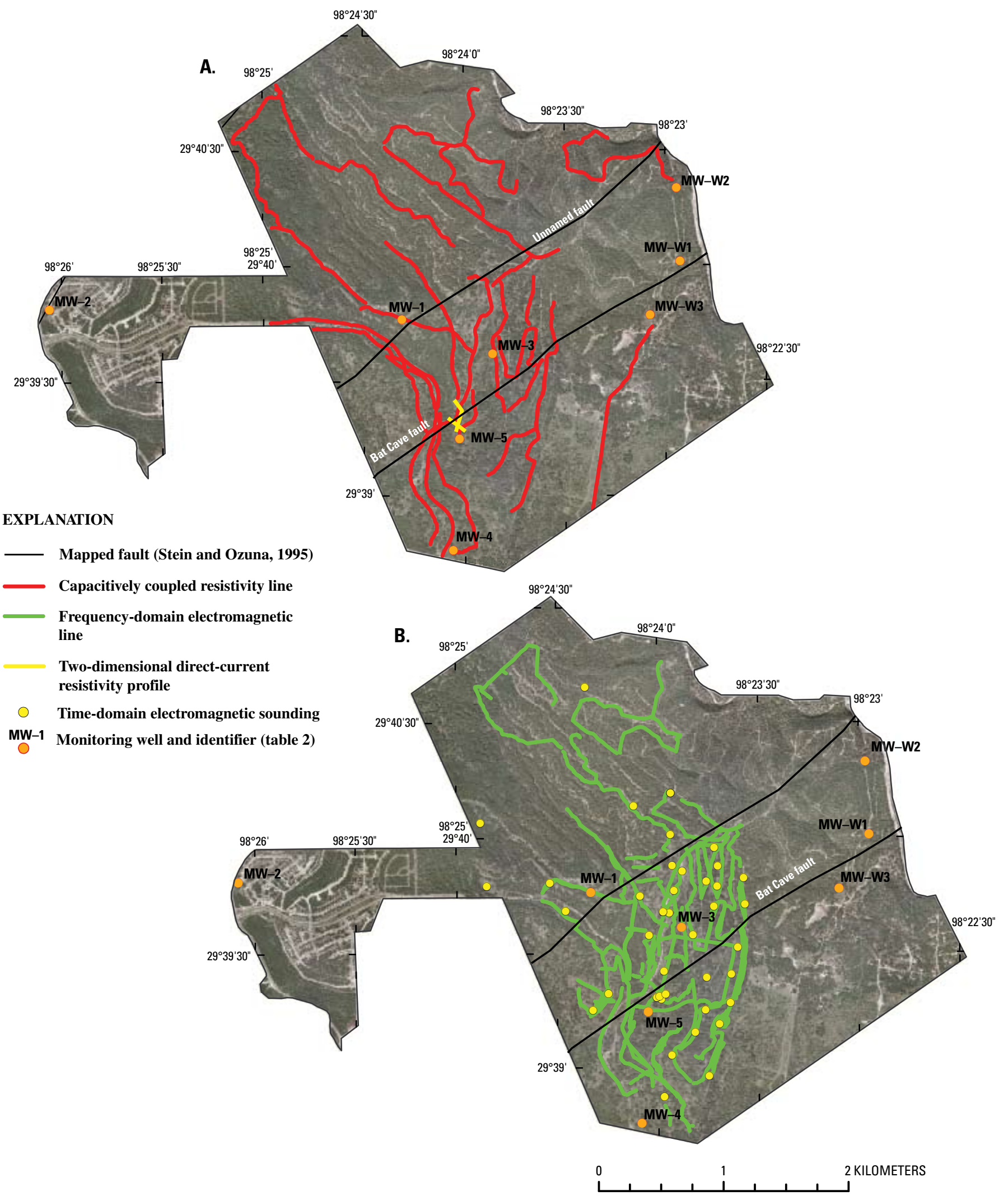

Figure 2. Hydrogeologic and geophysical study area, northeastern Bexar County, Texas, with locations of (A) capacitively coupled resistivity survey lines and two-dimensional direct-current resistivity profiles; and (B) frequency-domain electromagnetic lines and timedomain electromagnetic soundings. 


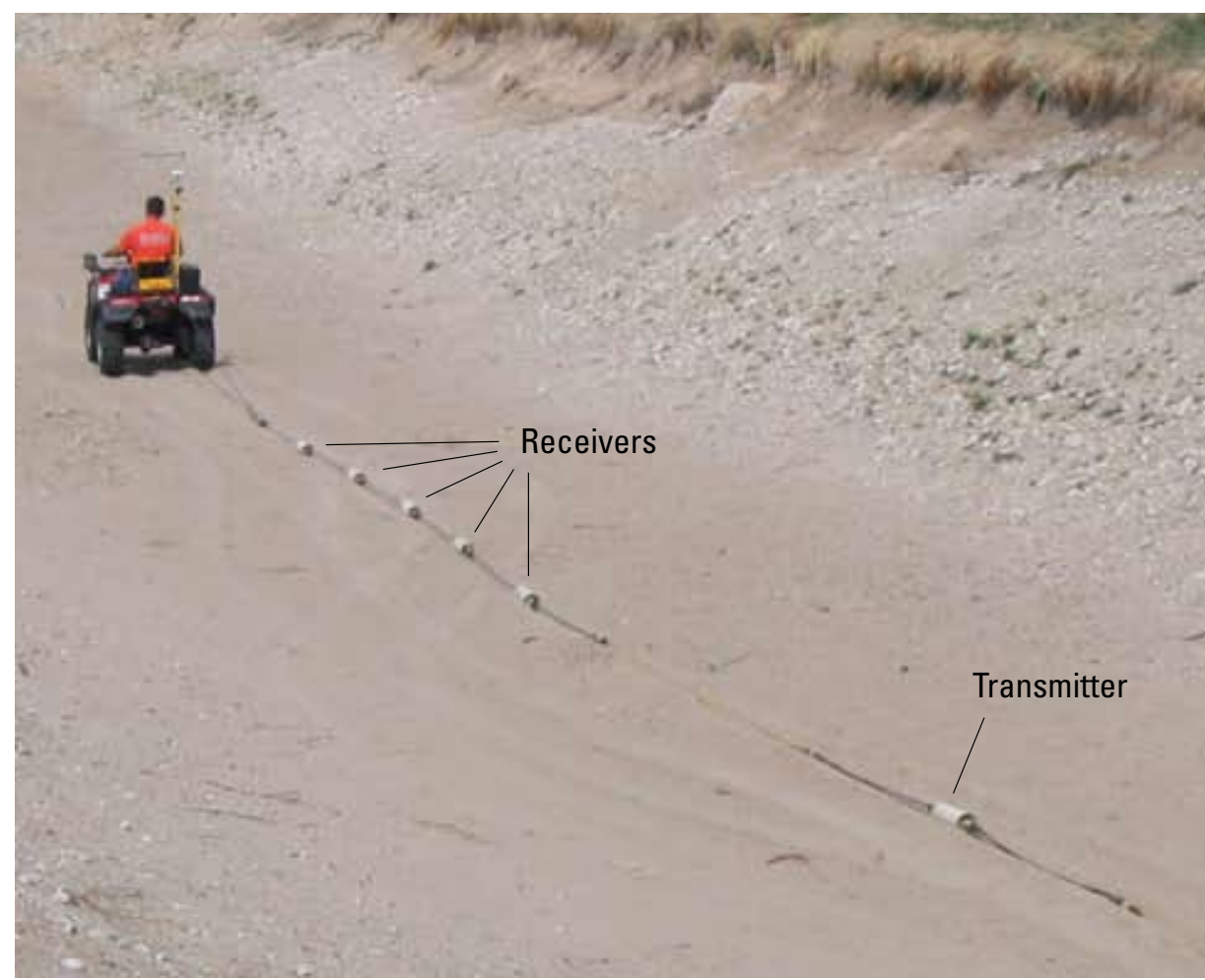

Figure 3. OhmMapper TR-5 capacitvely coupled array resistivity system (one transmitter and five receivers) towed by an all-terrain vehicle. ated. A dipole-dipole array with an antenna length of $10 \mathrm{~m}$ and an antenna separation distance of $5 \mathrm{~m}$ produced the best results and was used to collect all CC resistivity data for each survey line. The dipole-dipole array is good for mapping vertical structures such as dikes or caverns but relatively poor for mapping horizontal structures. A disadvantage to using the dipole-dipole array is a decrease in signal strength for relatively large distances between transmitter and receiver(s), making it more susceptible to environmental noise than other arrays (Loke and others, 2003; Loke, 2004).

By using multiple receivers with a single transmitter, data at different depth intervals can be collected simultaneously, allowing a vertical resistivity profile to be collected with a single current transmission. Because the electrical relation with the ground is developed through capacitance, electrical contact can be achieved without driving electrodes into the subsurface. Therefore, measurements can be made

Table 2. Location and construction information for monitoring wells, hydrogeologic and geophysical study area, northeastern Bexar County, Texas.

[USGS, U.S. Geological Survey]

\begin{tabular}{clcccc}
\hline $\begin{array}{c}\text { USGS site } \\
\text { identifier }\end{array}$ & $\begin{array}{c}\text { Monitoring well identifier } \\
\text { and State well number, } \\
\text { if available } \\
\text { (fig. 1) }\end{array}$ & $\begin{array}{c}\text { Easting } \\
\text { (meters) }\end{array}$ & $\begin{array}{c}\text { Northing } \\
\text { (meters) }\end{array}$ & $\begin{array}{c}\text { Well depth } \\
\text { (meters above } \\
\text { NAVD 88) }\end{array}$ & $\begin{array}{c}\text { Land-surface altitude } \\
\text { (meters above } \\
\text { NAVD 88) }\end{array}$ \\
\hline-- & MW-1 & $557,553.05$ & $3,281,567.18$ & 327.00 & 322.51 \\
293951098260401 & MW-2, AY-68-21-8 & $554,730.01$ & $3,281,645.37$ & 300.00 & 338.31 \\
293939098235501 & MW-3, AY-68-21-9 & $558,280.30$ & $3,281,293.92$ & 325.00 & 315.45 \\
293848098240701 & MW-4, AY-68-21-9 & $557,965.83$ & $3,279,722.50$ & 394.00 & 309.36 \\
293917098240201 & MW-5, AY-68-21-9 & $558,014.98$ & $3,280,615.38$ & 354.00 & 326.12 \\
-- & MW-W1 & $559,781.79$ & $3,282,040.56$ & 304.00 & 278.11 \\
294020098225701 & MW-W2, AY-68-21-6 & $559,751.79$ & $3,282,625.22$ & 301.00 & 278.88 \\
\hline 293946098230601 & MW-W3, AY-68-21-902 & $559,542.15$ & $3,281,608.36$ & 329.00 & 295.03 \\
\hline
\end{tabular}

\footnotetext{
${ }^{1}$ Estimated from USGS topographic sheet.
} 
while an array is pulled slowly along the land surface. The TR-5 was towed along newly bulldozed pathways with an all-terrain vehicle (fig. 3). Array details are listed in table 3 . A differentially corrected global positioning system was used to collect geospatial data during the $\mathrm{CC}$ resistivity survey.

\section{Frequency-Domain Electromagnetic Survey}

The FDEM method complements the $\mathrm{CC}$ resistivity method and can be useful for quality assurance and control by visually comparing resistivity profiles obtained using each method. In FDEM surveys, multiple current frequencies are used to measure conductivities of the earth at different depths. This is done by injecting an alternating current into a transmitter (Tx) coil at a known frequency. The current induces a primary magnetic field. The primary magnetic field creates a current in the subsurface, which in turn induces a secondary magnetic field. The magni-

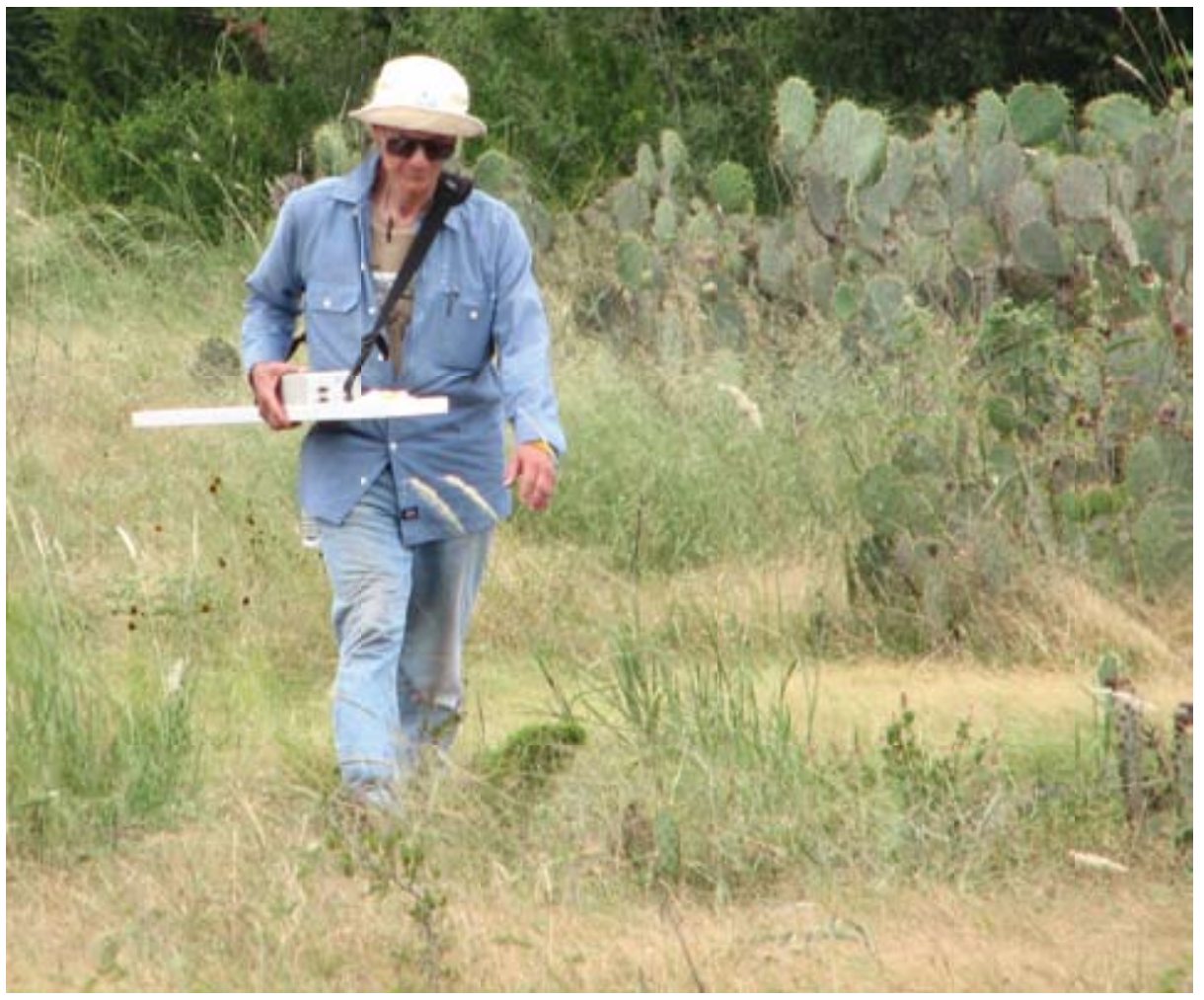

Figure 4. GEM-2 frequency-domain electromagnetic conductivity meter. tude of the primary magnetic field and the secondary magnetic field are measured by a receiver coil. On the basis of the measured field magnitudes, the in-phase and quadrature (90 degrees out of phase) responses are calculated, which are then used to calculate the apparent resistivity of the subsurface.

The FDEM surveys were done with a GEM-2 (fig. 4), a broadband, multifrequency, fixed-coil electromagnetic induction instrument (Geophex, Ltd., 2007). Three small coils are in the GEM-2: a transmitter coil, a receiver coil, and a bucking coil that removes the primary field from the receiver signal. Software in the instrument calculates the in-phase and quadrature responses in units of parts per million of the primary field, which represent the scaled ratio of the secondary magnetic field to the primary magnetic field at the receiver coil. More information about the GEM-2 and its operating principles are discussed in Won and others (2006).

The GEM-2 was operated in vertical-dipole mode (horizontal coplanar coils, or loops) with fixed spacing $(1.67 \mathrm{~m})$ between coils. Five frequencies were used: 6,270, 12,030, 24,450, 31,470, and 43,530 hertz (Hz) (table 4). An environmental noise test was done before beginning the FDEM survey to aid in selecting frequencies that did not interfere with natural or anthropogenic electromagnetic noise in the area. Although no power-transmission lines were present in the immediate area, the $60 \mathrm{~Hz}$ frequency was monitored throughout the survey, and harmonic frequencies of $60 \mathrm{~Hz}$ were avoided.

Calibration sites, or base stations, were set up to aid in correction of drift (shift in the response over time measured by the instrument) so that static values of electromagnetic data could be measured and compared to data collected at points on nearby FDEM survey lines at different times throughout the survey. At the beginning and end of each day that FDEM data were collected, the GEM-2 was placed at these calibration sites, and approximately 3 to 5 minutes of data were collected for calibration.

\section{Time-Domain Electromagnetic Soundings}

Forty-four TDEM soundings were collected (of which 29 were used) over the area covered by CC resistivity lines and FDEM lines (fig. 2). Areal gaps in the data occur because of difficulties deploying the TDEM system in undeveloped parts of the study area. Two TDEM instruments (the Geonics Protem and the Alpha Geophysics TerraTEM) were used, and the data collected with each were compared for quality. The Geonics Protem-47 and -57 systems (Geonics Ltd., 2005) used eight 40-m by 40-m square loops to collect the TDEM soundings. The Alpha Geophysics TerraTEM system (Monash GeoScope, 2007) was used to collect thirty-six 40-m by 40-m square-loop TDEM soundings. The TerraTEM uses the same physical principles as the Geonics Protem systems, but rather than a fixed loop-receiver as the Geonics systems (fig. 5), it uses a coincident-loop receiver that is parallel to the 
A.

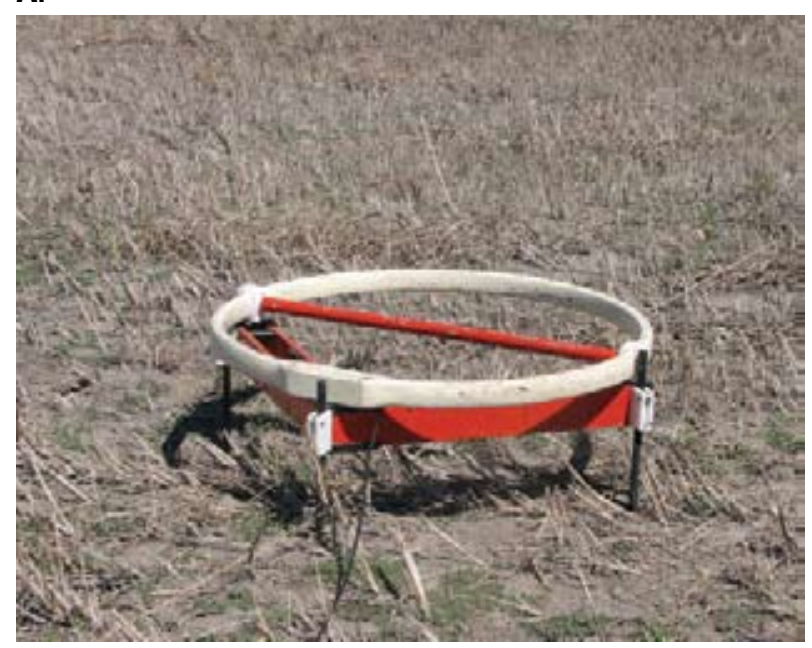

B.

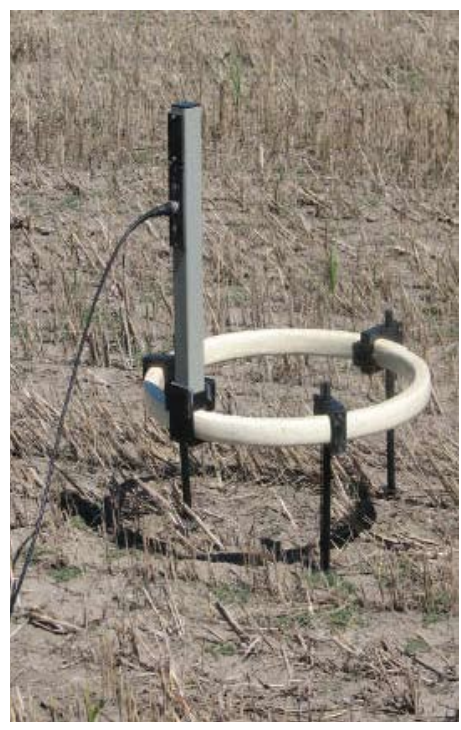

C.

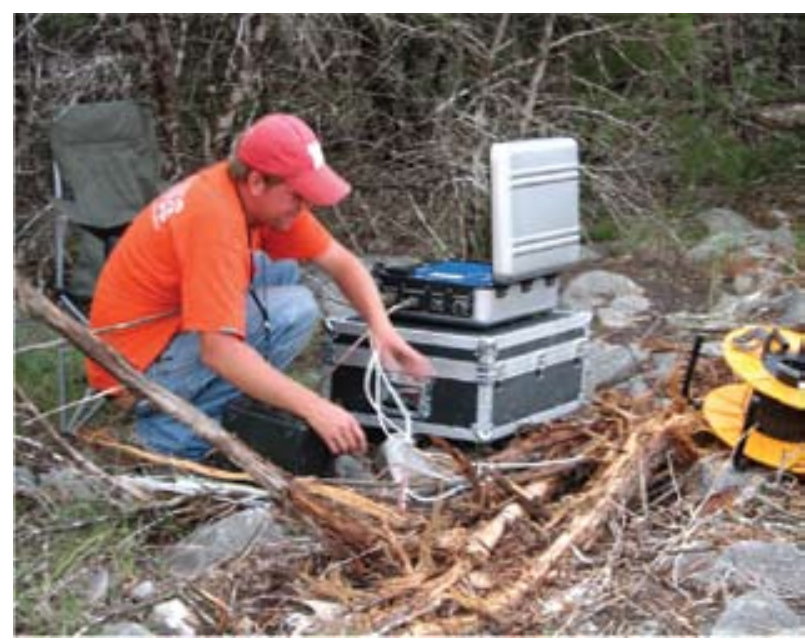

Figure 5. (A) Receiver coil (loop) for Geonics Protem-57, (B) receiver coil for Geonics Protem-47, and (C) Alpha Geophysics TerraTEM console, which contains the receiver coil.
Table 3. Capacitively coupled and two-dimensional directcurrent resistivity field parameters used during data collection, hydrogeologic and geophysical study area, northeastern Bexar County, Texas.

[--, not applicable]

\begin{tabular}{ccccc}
\hline Tool & $\begin{array}{c}\text { Array } \\
\text { type }\end{array}$ & $\begin{array}{c}\text { Dipole } \\
\text { length } \\
\text { (meters) }\end{array}$ & $\begin{array}{c}\text { Dipole } \\
\text { separation } \\
\text { factor }\end{array}$ & $\begin{array}{c}\text { Approximate } \\
\text { depth of } \\
\text { penetration } \\
\text { (meters) }\end{array}$ \\
\hline $\begin{array}{l}\text { Capacitively } \\
\text { coupled } \\
\text { resistivity }\end{array}$ & Dipole-dipole & 10 & $0.5,1.0,1.5$, & 7.5 \\
$\begin{array}{c}\text { Direct-current } \\
\text { resistivity }\end{array}$ & & $2.0,2.5$ & \\
& $\begin{array}{l}\text { Hybrid } \\
\text { Wenner- }\end{array}$ & -- & -- & 45 \\
\hline
\end{tabular}

Table 4. Frequency-domain electromagnetic field parameters used during data collection, hydrogeologic and geophysical study area, northeastern Bexar County, Texas.

\begin{tabular}{ccccc}
\hline Instrument & $\begin{array}{c}\text { Array type or } \\
\text { configuration }\end{array}$ & $\begin{array}{c}\text { Coil/loop } \\
\text { separation } \\
\text { (meters) }\end{array}$ & $\begin{array}{c}\text { Frequencies } \\
\text { used } \\
\text { (hertz) }\end{array}$ & $\begin{array}{c}\text { Approximate } \\
\text { depth of } \\
\text { investigation } \\
\text { (meters) }\end{array}$ \\
\hline Geophex & Multifrequency, & 1.67 & 6,270 & 5.5 \\
GEM-2 & fixed & & 12,030 & \\
& separation & & 24,450 & \\
& & & 31,470 & \\
& & 43,530 & \\
\hline
\end{tabular}

transmitting loop (Monash GeoScope, 2007). Table 5 shows the time-domain electromagnetic sounding field parameters used during data collection at the site. IX1D version 3.36 (Interpex Ltd., 2007), was used to display and visually analyze and do smooth and layered-earth inverse modeling of the apparent resistivity data.

\section{Direct-Current Resistivity Survey}

The IRIS Instruments Syscal Pro system (fig. 6) (IRIS Instruments, 2006) was used to collect two 2D-DC profiles of apparent resistivity data using a dipole-dipole and hybrid Wenner-Schlumberger arrays. Reciprocal arrays (reverse dipole-dipole and reciprocal Schlumberger) were collected for quality assurance and control. The theorem of reciprocity states that no change will be observed in the ratio of measured voltage to the imposed current if the positions of the potential electrodes and of the current electrodes are interchanged; therefore the reciprocal arrays should have the same lateral and vertical resolution as the original arrays (Keller and Frischknecht, 1966). Visual inspection of apparent resistivity 
A.

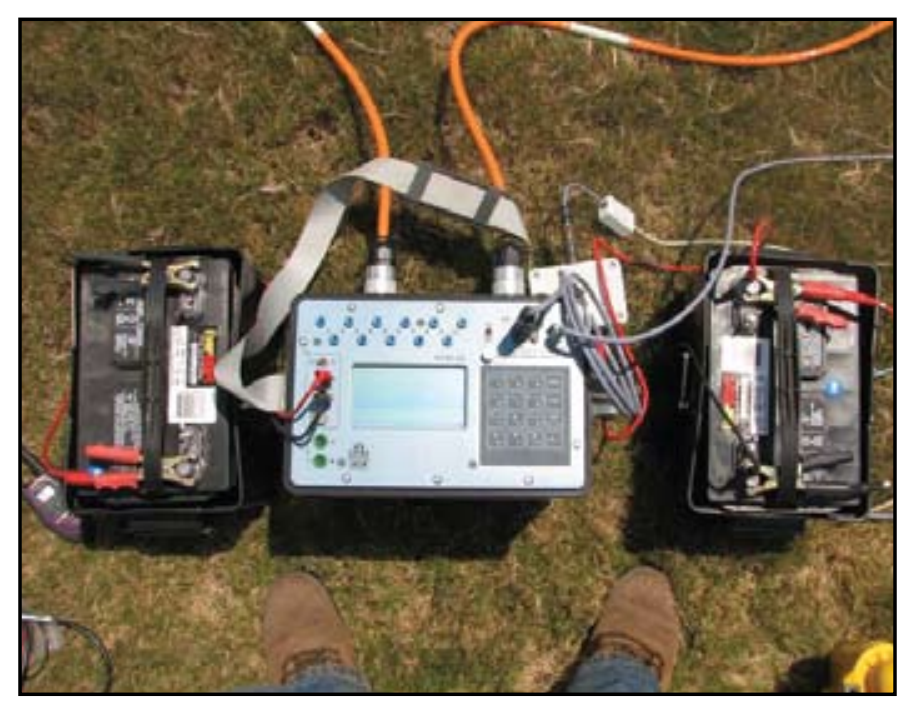

B.

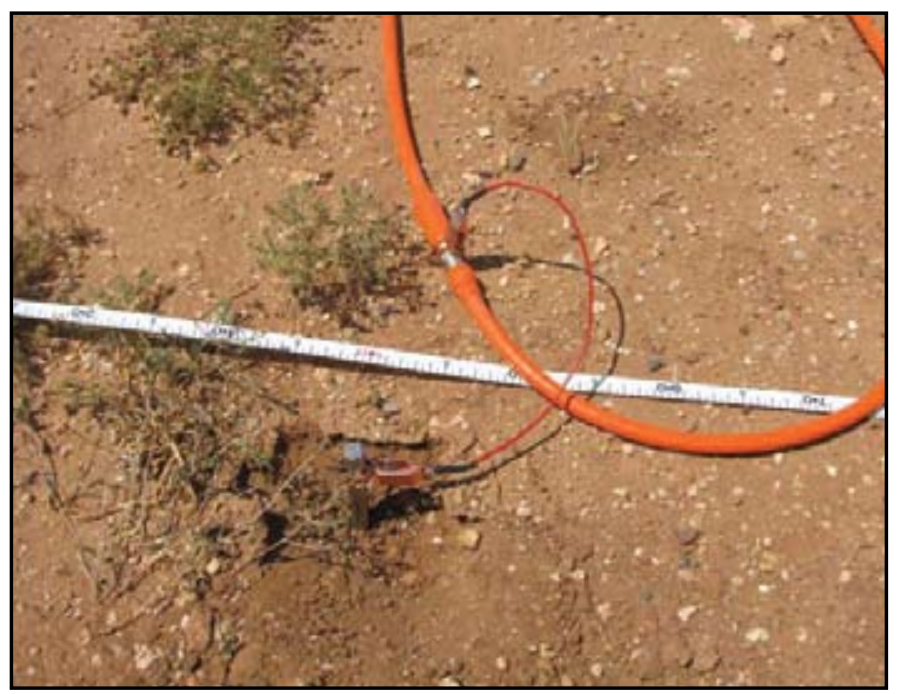

Figure 6. (A) IRIS Syscal Pro resistivity system connected to multi-conductor cables and (B) stainless steel electrode take-out built into multi-conductor cable.

Table 5. Time-domain electromagnetic sounding field parameters used during data collection, hydrogeologic and geophysical study area, northeastern Bexar County, Texas.

[--, not applicable]

\begin{tabular}{|c|c|c|c|c|}
\hline Instrument & $\begin{array}{l}\text { Array type or } \\
\text { configuration }\end{array}$ & $\begin{array}{l}\text { Coil/loop separation } \\
\text { (meters) }\end{array}$ & $\begin{array}{l}\text { Frequencies used } \\
\text { (hertz) }\end{array}$ & $\begin{array}{l}\text { Approximate depth } \\
\text { of investigation } \\
\text { (meters) }\end{array}$ \\
\hline Alpha Geophysics TerraTEM & $\begin{array}{l}40 \text {-meter by } 40 \text {-meter square } \\
\text { coincident loop }\end{array}$ & 1 & 10 & 125 \\
\hline Geonics Protem & $\begin{array}{l}40 \text {-meter by } 40 \text {-meter square } \\
\text { coincident loop }\end{array}$ & -- & $\begin{array}{c}3 \\
7.5 \\
30 \\
75 \\
280\end{array}$ & 125 \\
\hline
\end{tabular}

pseudo-sections ${ }^{1}$ for each of the arrays and its reciprocal were used to verify that no equipment or field-induced biases occurred during data collection. The raw field data (current and voltage) also were reviewed for measurement uncertainty by evaluating the minimum and maximum current (transmitter) and voltage (receiver) values as well as the standard deviation of the computed apparent resistivity data using Prosys II version 2.15 (IRIS Instruments, 2006). No filtering was needed because the raw field data and computed apparent resistivity data for each array had relatively high signal-tonoise ratios. Apparent 2D-DC resistivity data were inverted using RES2DINV version 3.56 (Loke, 2004). Smooth and

\footnotetext{
${ }^{1}$ Pseudo-sections are contoured sections of apparent resistivity that look like resistivity sections of the ground but they are not-they are simply graphical representations of the data (Morrison and others, 2004).
}

blocky inversion techniques were used to invert the dipoledipole and hybrid Wenner-Schlumberger data (Loke and others, 2003) that were collected.

\section{Processing and Inverse Modeling Results of Surface Geophysics Data}

Datasets of raw and processed data from all geophysical surveys are in appendix 1.

\section{Capacitively Coupled Resistivity}

The CC apparent resistivity data, transformed from raw CC data by pre-processing software, were statistically 
analyzed and filtered by deleting data points with less than 5 microvolts and apparent resistivities greater than 2,500 ohmmeters (ohm-m). The remaining apparent resistivities were filtered using a 5-m sliding-window average laterally across the section for each discrete depth level. The filtered data were then inverted using AGI EarthImager 2-D inversion software (Advanced Geosciences, Inc., 2007).

The inversion results (estimated true resistivities) for each CC line were entered into the geospatial database in array format (Geosoft Inc., 2007). Each array has a depth and corresponding resistivity for each point along the line. Initially, grids were generated for multiple depths across the area. This was done to assess electrical changes with depth. Changes with depth could potentially indicate hydrostratigraphic zones that are shallower than the penetration depth of the OhmMapper, which is about $7.5 \mathrm{~m}$.

A depth of about $4 \mathrm{~m}$ below land surface (referred to as depth level four) was determined to be the most precise and representative of the depth profile. Depth level four corresponds to receiver one of the OhmMapper TR-5 configuration. The signal-to-noise ratio for the depth corresponding to receiver one is higher than the ratios for depths corresponding to receivers farther away from the transmitter than receiver one, and therefore results from the first receiver usually have the highest-data quality. Data from receivers other than receiver one were considered less reliable.

Each grid also was analyzed for lateral changes. Lateral changes potentially could aid in refining the map of surface geology. Only minor lateral changes were observed, and only in the layers deeper than $4 \mathrm{~m}$, which can be attributed to lower signal-to-noise ratios.

\section{Frequency-Domain Electromagnetic Survey}

The processing of the FDEM data was done using the Helicopter Electromagnetic (HEM) module of Oasis montaj v.6.4.2 (Geosoft, 2007). This processing module allows for filtering, data leveling (correction for altitude errors at line intersections), and calculation of apparent resistivity. First, the data quality was evaluated and excess electromagnetic noise filtered out. Data from FDEM instruments are shown as an in-phase and quadrature response. Because of oscillations in the quadrature data, a low-pass filter with a window length of 50 points, which corresponds to approximately a 5-m horizontal distance, was used. The quadrature response at each calibration site was very stable and showed minimal variation due to instrument drift during the calibration datacollection time. Data from each base station were filtered using the same 50-point low-pass filter to remove excessive oscillations.

Despite the fact that the measurements at the base stations were stable, during the FDEM survey (14 days), a drift of several hundred parts per million was observed in the quadrature response; thus a drift correction was necessary. Drift was corrected for using a recent technique developed by the U.S. Geological Survey Imaging and Characterization Team,
Denver, Colo. (Jared Abraham, U.S. Geological Survey, written commun., 2007).

To calibrate the FDEM data, CC resistivity and 2D-DC resistivity data were used to provide resistivity models near each calibration site. Forward model calculations from each of these resistivity models, obtained using the software EM1D (Kim and others, 1997), provided parts-per-million values of the quadrature response near each calibration site. The filtered and leveled data were adjusted to match the calculated parts-per-million values. To check the consistency of the data, neighboring lines were compared directly to determine if they resulted in reasonably close resistivity values (a judgment decision) and also to verify that the lines near the calibration sites held values close to the calibration value.

After each GEM-2 profile was calibrated, the Oasis montaj HEM module was used to calculate apparent resistivity of the quadrature data at each frequency using the calibrated data (Geosoft Inc., 2007). Figure 7 shows examples of the raw quadrature data collected at a base station with filtered data used in processing superimposed, raw quadrature data collected along an FDEM line with filtered data superimposed, and apparent resistivity along an FDEM line calculated from uncalibrated and calibrated (to $\mathrm{CC}$ resistivity data) quadrature data.

\section{Time-Domain Electromagnetic Soundings}

For each sounding, raw voltage data were statistically analyzed to filter the data before inversion. All negative gate voltages (voltages measured by the receiver coil in small intervals of time called gates), and replicate gate voltages exceeding a relative standard deviation of 10 percent, were eliminated from the dataset. The trimmed mean (20-percent trim level $\left.{ }^{2}\right)$ of the remaining data was then calculated to provide the voltages used for the inversion process.

The voltage data were imported into the inverse modeling software IX1D version 3.36 (Interpex Ltd., 2007) to visually analyze and do smooth and layered-earth inverse modeling of the apparent resistivity data. Voltages with standard deviation greater than 5 percent were deleted before modeling, which eliminated data from noisy, late-time gates. The apparent resistivity data were then graphed as a function of time on a logarithmic scale. Data points that deviated severely (a judgment decision) from a curve fitted to the data were deleted before inverse modeling. A smooth model consisting of 25 layers with a minimum depth of $1 \mathrm{~m}$, a maximum depth of $125 \mathrm{~m}$, and a starting resistivity of $25 \mathrm{ohm}-\mathrm{m}$ were used to approximate the measured resistivity points in the starting model. The smooth modeling technique is based on Occam's inversion principle (Constable and others, 1987). A simple layeredearth forward model (Interpex Ltd., 2007) was constructed on the basis of inflections observed in the smooth model. This forward model inversion was completed until the model curve fit the data points with a minimal RMS error. Inversion of the

\footnotetext{
${ }^{2}$ Ranked data with uppermost 10 percent and lowermost 10 percent deleted.
} 

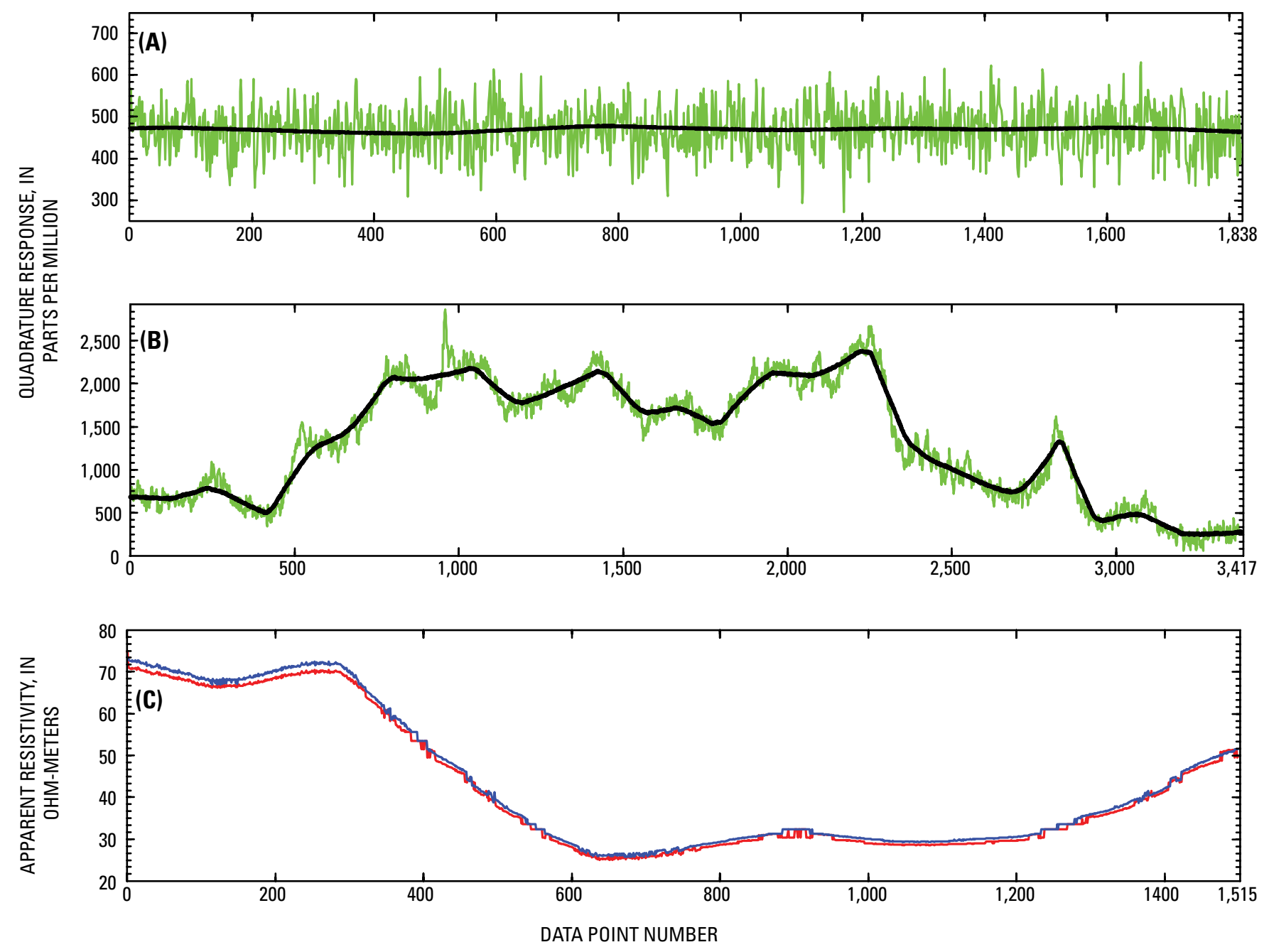

EXPLANATION
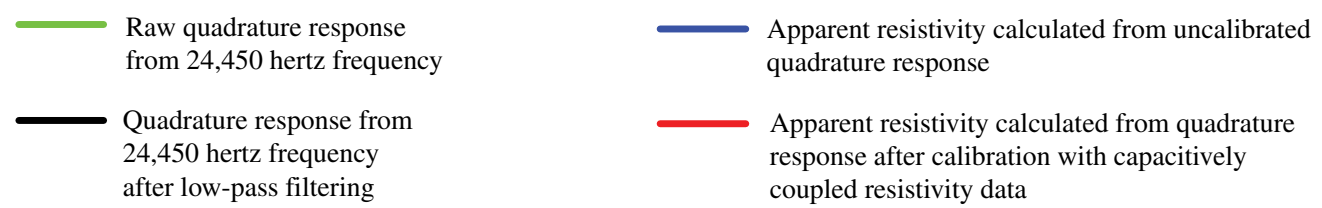

Figure 7. Graphs developed from frequency-domain electromagnetic data showing examples of $(A)$ raw quadrature data collected at a base station with filtered quadrature data superimposed, (B) raw quadrature data collected along a frequency-domain electromagnetic line with filtered quadrature data superimposed, and $(C)$ apparent resistivity along a frequency-domain electromagnetic line calculated from uncalibrated and calibrated (to capacitively coupled resistivity data) quadrature data, hydrogeologic and geophysical study area, northeastern Bexar County, Texas.

forward model was done using the ridge regression inverse modeling method (Inman, 1975), which attempts to best-fit the data while minimizing the change in the smooth model. Layered-earth models were constructed with two to three layers for each sounding. The root mean square (RMS) error was less than 10 percent for each sounding on the site. The RMS error values were used to evaluate the precision of each sounding. A sounding with an RMS error greater than 7.5 percent was given less weight than the others because of the uncertainty in the data. After each sounding was inverted in IX1D version 3.36, the layered-earth model was imported into the geodatabase to compare with other soundings along the same profile.

\section{Direct-Current Resistivity}

The IRIS Instruments Syscal Pro system was used to collect two 2D-DC profiles of apparent resistivity data using the 
dipole-dipole and hybrid Wenner-Schlumberger arrays (IRIS Instruments, 2006). The raw field dataset was imported into the 2D inverse modeling software RES2DINV version 3.56 (Loke, 2004). RES2DINV was used to complete a five-iteration, least-squares inversion. The RMS error between the measured and calculated apparent resistivity for each array was less than 4 percent. The authors judge RMS errors of 10 percent or less to be good. To further review the inversion results, the RMS error statistics (the distribution of the percentage difference between the logarithms of the observed and calculated apparent resistivity values) were evaluated (Loke, 2004). Field data that did not fit the distribution, "outliers," were removed, and the data were re-inverted. No data were removed from the hybrid Wenner-Schlumberger array inversions, and only a few data points were removed from the dipole-dipole arrays. Analysis of the RMS error statistics for a second five-iteration inversion of the dipole-dipole arrays indicated that no additional data needed to be removed. In most cases, the 2D-DC resistivity data model resolves lateral and vertical changes in electrical resistivity across Bat Cave fault, as described in the next section.

\section{Hydrostratigraphic Characterization from Hydrogeologic Mapping and Geophysical Data}

The principal finding of this investigation is the relation between electrical resistivity and the contacts between the hydrostratigraphic zones of the Edwards aquifer and the underlying Trinity aquifer in the study area. In general, the different hydrostratigraphic zones have identifiable differences in electrical resistivity based on their mineralogy, rock type, and water content (Smith and others, 2003, 2007). In general, the upper hydrostratigraphic zones (II through IV, Person Formation) (table 1) of the aquifer have proportionately greater amounts of mudstone and wackestone than the lower hydrostratigraphic zones (V through VIII, Kainer Formation), rock types associated with relatively low resistivity/high relative conductivity (and relatively low permeability). The highest relative resistivity/lowest relative conductivity (and highest relative permeability) is associated with crystalline limestone in hydrostratigraphic zones III (leached and collapsed members, undivided), VI (Kirschberg evaporite member), and VII (dolomitic member).

\section{Vertical Structure Based on Resistivity Variation}

The TDEM data are used to indicate vertical structure and altitude of the hydrostratigraphic zones. In general, the TDEM data indicate a two-layer model in which an electrical conductor underlies an electrical resistor, which is consistent with the Trinity aquifer (conductor) underlying the Edwards aquifer (resistor). However, TDEM data could not be used to delineate the various hydrostratigraphic zones of the Edwards aquifer continuously with depth because resistivities of each zone were not different enough to delineate differences in lithology. Geologic (hydrostratigraphic) section $A-A$ ' trending northsouth in the study area (plate 1) was constructed from four wells and three TDEM soundings. The section shows the offsetting geologic units and equivalent hydrostratigraphic zones of the Edwards aquifer and geologic units of the upper zone of the Trinity aquifer. Known faults such as Bat Cave fault and interpreted faults from hydrogeologic mapping for this report place hydrostratigraphic zones composed of younger rocks adjacent to hydrostratigraphic zones composed of older rocks. Laterally (at land surface), the TDEM soundings transect Bat Cave fault and change from hydrostratigraphic zone VI (older rocks) on the north side of the fault to hydrostratigraphic zone III (younger rocks) on the south (downthrown) side. Based on historical borehole log data (indicating only the hydrostratigraphic zones VII and VIII), the fault is vertically displaced by about $30 \mathrm{~m}$ (U.S. Geological Survey, unpub. data, 2007). This displacement serves as a baseline for TDEM interpretation. Based on TDEM soundings indicating the Edwards aquiferTrinity aquifer contact (plate 1), the thicker vertical section of the aquifer is on the downthrown side of the fault, where the thickness at the fault is about $120 \mathrm{~m}$; on the upthrown side, the thickness is about $60 \mathrm{~m}$; thus the displacement from TDEM data is about $60 \mathrm{~m}$, twice that from previously obtained borehole log data. The resistivity values defining the Edwards aquifer-Trinity aquifer contact (altitude of the base of the Edwards aquifer) range from 5 to $180 \mathrm{ohm}-\mathrm{m}$.

Conceptually, vertical structural features can be either barriers or preferential pathways for ground-water flow, as described by Maclay and Small (1976). An example of a lateral ground-water-flow barrier is a clay "seal" that forms along a fault plane. Another is a situation in which faulting has juxtaposed relatively impermeable (confining) units on the down gradient side of permeable (aquifer) units, Thus knowing the amount of fault displacement and the local hydrostratigraphy can contribute to understanding groundwater flow in the study area. For example, resistivity-depth sections (figs. 8, 9) and interpretation of surface geology indicate that because of fault displacement, relatively permeable hydrostratigraphic zone III (leached and collapsed members, undivided) on the south (downthrown) side of Bat Cave fault is juxtaposed against relatively permeable hydrostratigraphic zone VII (dolomitic member) on the north side of the fault; thus there could be flow across the fault at the site of data collection if there is not a "seal." However, the resistivity-depth sections also show the Bat Cave fault plane to be associated with a local, nearly vertical zone of low resistivity that can be interpreted as fault gouge (ground-up rock resulting from friction associated with fault movement) or clay filling along the fault, which if present could impede local ground-water flow across the fault. According to previous investigations (Rose, 1972; Maclay and Small, 1976), Bat Cave fault might present a barrier to flow. A more definitive answer to the question of 


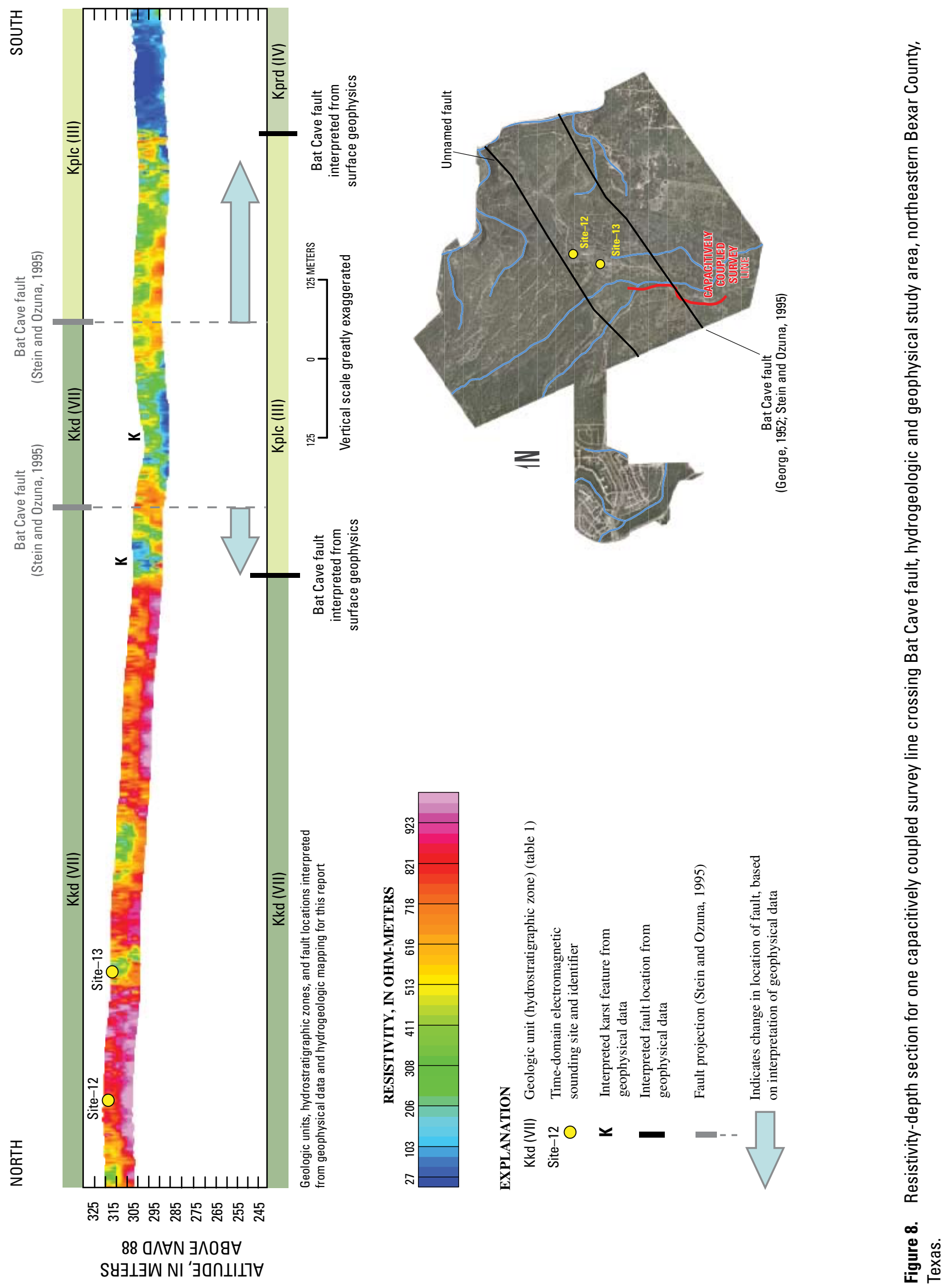




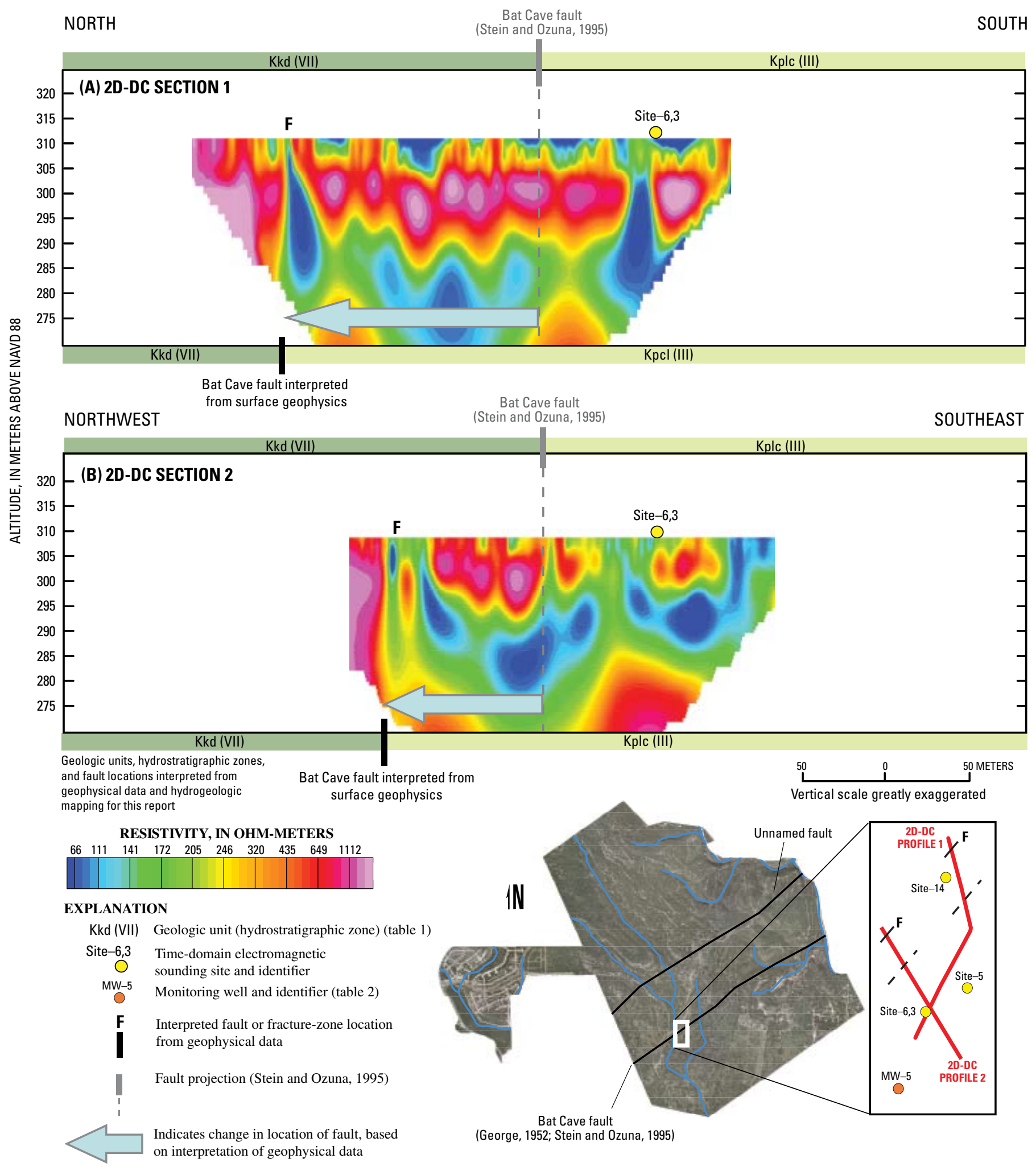

Figure 9. Resistivity-depth sections for two-dimensional direct-current (2D-DC) resistivity profiles (A) 1 and (B) 2 with time-domain electromagnetic sounding locations, hydrogeologic and geophysical study area, northeastern Bexar County, Texas. 
barrier or not would require more study, but these reconnaissance data provide evidence for Bat Cave fault functioning as a barrier, at least locally.

\section{Lateral Structure Based on Resistivity Variation}

The CC resistivity, FDEM, and 2D-DC resistivity surveys provide sufficient data resolution for determining lateral resistivity variation in the study area and thus for estimating ranges of resistivity for each hydrostratigraphic zone of the Edwards aquifer (table 6). In general, the geophysical data show a sharp electrical contrast from north to south, changing from high resistivity to low resistivity across Bat Cave fault (fig. 10) as well as possible karst features in the study area.

Karst features can have an electrical signature ranging from resistive to highly conductive. In the study area, nearsurface karst features such as caverns and sinkholes might be filled with water, clay, soil, or some combination of these, or they might be open and filled with air. Water- or air-filled voids might be connected to deeper voids. Thus, karst features might be anomalously low-resistivity areas if they are filled with water, clay, or soil, whereas near-surface air-filled voids might be anomalously high-resistivity areas. Anomalously low-resistivity areas in mostly resistive hydrostratigraphic zones VII and III shown in the CC resistivity-depth section of figure 8 are interpreted as karst features.

The CC resistivity-depth section of figure 8 shows distinct changes in near-surface resistivity along the survey line. One such change is observed in the section about $110 \mathrm{~m}$ north of Bat Cave fault, as located in Stein and Ozuna (1995). Moving north to south, a highly resistive (600 to greater than 900 ohm-m) zone transitions to a moderately resistive (200-600 ohm-m excluding anomalous lows) zone. The change was interpreted as the transition from hydrostratigraphic zone VII (dolomitic member) across Bat Cave Fault to hydrostratigraphic zone III (leached and collapsed members, undivided). Another change occurs about $160 \mathrm{~m}$ from the southern end of the section. Moving north to south, a moderate resistivity (250-600 ohm-m) zone transitions to a very low resistivity low resistivity (25-80 ohm-m) zone. Multiple continuous CC resistivity survey lines (fig. 10) were collected that crossed the mapped faults of Stein and Ozuna (1995), and the same distinct high-to-low change close to the Stein and Ozuna (1995) location of Bat Cave fault is apparent in each line except one east of well MW-3. Also, the CC resistivity-depth section shows a relatively large low-resistivity (high-conductivity) area between the two points at which the CC survey line (fig. 8) crosses Bat Cave fault. This area is interpreted as possible karst (sinkholes) or intensely fractured rock in which the voids have been filled with clay and conductive soil.

A low-resistivity (high-conductivity) area observed in hydrostratigraphic zone III (leached and collapsed members, undivided) south of Bat Cave fault (fig. 10) corresponds to a known sinkhole. The sinkhole is well defined because CC and FDEM data were intentionally collected in the area multiple times to obtain an exceptionally detailed electrical signature of the karst feature. The sinkhole, which at the time of data collection was retaining water, supports the assumption that karst features in the study area might be filled with clay or other soils that might help in retaining water. Other potential karst areas - areas of low resistivity (high conductivity) - are apparent from the CC resistivity and FDEM data throughout the site (fig. 10).

In 2D-DC resistivity-depth section 1 (fig. 9A), about 80 $\mathrm{m}$ from the north end of profile 1 , a solitary vertical conductive feature occurs. All areas north of this point on the section are highly resistive (greater than $600 \mathrm{ohm}-\mathrm{m}$ ). This vertical low-resistivity (high-conductivity) zone could be a fault or fracture zone. 2D-DC resistivity-depth section 2 (fig. 9B) shows a small low-resistivity zone at relatively the same location as the one in section 1 . The low-resistivity zone in section 2 ranges from about 60 to $170 \mathrm{ohm}-\mathrm{m}$, whereas the resistivity in section 1 is about $60 \mathrm{ohm}-\mathrm{m}$. The 2D-DC resistivity sections correlate well with the CC resistivity section (fig. 8) showing an electrical change approximately $110 \mathrm{~m}$ north of interpreted location of Bat Cave fault.

\section{Integration of Hydrogeologic Mapping and Geophysical Data}

Comparison of hydrogeologic mapping and geophysical data was accomplished by overlaying the surface geology map of Stein and Ozuna (1995) (plate 1) with computer-generated grids representing variations in resistivity from the $\mathrm{CC}$ resistivity and FDEM surveys. Geologic (hydrostratigraphic) contacts were then adjusted on the basis of estimated resistivity ranges for the hydrostratigraphic units (table 6). Fault locations also were modified by comparing mapped fault locations with breaks in resistivity. The only contacts and faults that were shifted on the basis of resistivity changes were those in areas that contained sufficient geophysical data. Existing or possible hydrogeologic features identified on the revised, or reinterpreted, surface geology map (plate 1) were based on resistivity differences. Newly mapped hydrogeologic features, such as potential karst features and fracture zones, are shown where their occurrence was supported by $\mathrm{CC}$ resistivity and FDEM resistivity data. Karst features that are water-filled result in relatively low resistivity, and karst features that are air-filled result in relatively high resistivity. Interpreted karst features that show relatively low resistivity within a relatively high-resistivity area likely are attributable to clays or soils filling a sinkhole. Inferred faults mapped primarily in the southern part of the study area are not identifiable from the geophysical data because the adjacent resistivities are not sufficiently different. In general, inferred faults are shown where lithologic incongruity at the surface indicates possible displacement along fault planes. Along most inferred faults, displacement was not sufficient to place different members of the Kainer or Person Formations (hydrostratigraphic zones) adjacent across the inferred fault plane. 


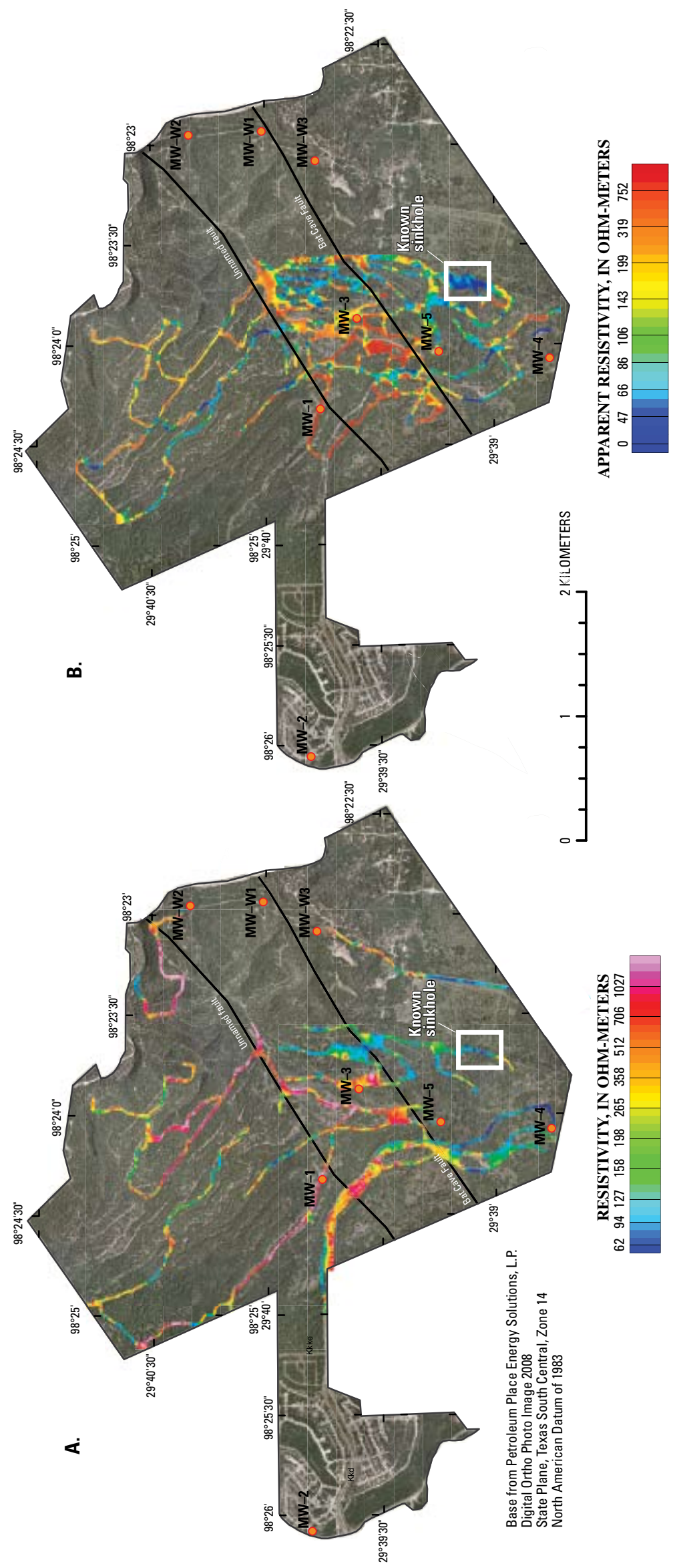

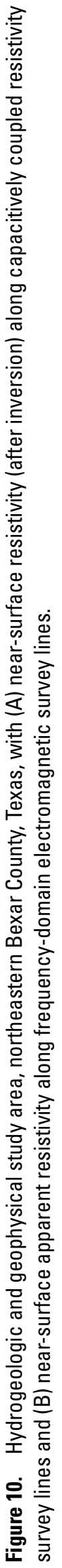


Table 6. Hydrogeologic characteristics from mapping and generalized ranges of resistivity, for hydrostratigraphic zones of the Edwards aquifer, hydrogeologic and geophysical study area, northeastern Bexar County, Texas.

\begin{tabular}{clc}
\hline $\begin{array}{c}\text { Edwards aquifer } \\
\text { hydrostratigraphic } \\
\text { zone }\end{array}$ & \multicolumn{1}{c}{$\begin{array}{c}\text { Hydrogeologic } \\
\text { characteristics } \\
\text { from local mapping }\end{array}$} & $\begin{array}{c}\text { Generalized true } \\
\text { resistivity range } \\
\text { (ohm-meters) }\end{array}$ \\
\hline II & Moderate porosity, high permeability, local low permeability in mudstone & $\begin{array}{c}\text { Moderate } \\
(100-300)\end{array}$ \\
\hline III & High porosity, high permeability & $\begin{array}{c}\text { High } \\
(300-500)\end{array}$ \\
\hline IV & Low porosity, low permeability, barrier to vertical flow & $\begin{array}{c}\text { Low } \\
\text { (less than 100) }\end{array}$ \\
\hline V & $\begin{array}{c}\text { Low porosity except in dissolution-enhanced fractures and bedding planes. Local high } \\
\text { permeability in dissolution-enhanced fractures and bedding planes and with conduit } \\
\text { development }\end{array}$ & $\begin{array}{c}\text { Moderate } \\
(100-300)\end{array}$ \\
\hline VI & $\begin{array}{c}\text { High porosity, moderate permeability, general lack of conduits; because of high porosity, } \\
\text { conduits cannot be structurally supported }\end{array}$ & $\begin{array}{c}\text { High } \\
(300-500)\end{array}$ \\
\hline VII & $\begin{array}{c}\text { Low porosity except in high permeability zones associated with fractures, bedding } \\
\text { planes, and cavern s }\end{array}$ & $\begin{array}{c}\text { Very high } \\
\text { (greater than 500) }\end{array}$ \\
\hline VIII & Low porosity, low permeability, local high permeability in conduits and bedding planes & $\begin{array}{c}\text { Moderate } \\
(100-300)\end{array}$ \\
\hline
\end{tabular}

In general, the Kainer Formation (hydrostratigraphic zones V through VIII) has a higher resistivity than the Person Formation (hydrostratigraphic zones II through IV). On the basis of calculated resistivities, highest to lowest, the hydrostratigraphic zones rank as follows: (1) zone VII, dolomitic member, (2) zone III, leached and collapsed members, undivided, (3) zone VI, Kirschberg evaporite member, (4) zone II, cyclic and marine members, (5) zone V, grainstone member, (6) zone VIII, basal nodular member, and (7) zone IV, regional dense member. Although resistivity variations from the CC resistivity, FDEM, and 2D-DC resistivity surveys, with mapping information, were sufficient to allow surface mapping of the lateral extent of hydrostratigraphic zones in places, resistivity variations from TDEM data were not sufficient to allow vertical delineation of hydrostratigraphic zones; however, the Edwards aquifer-Trinity aquifer contact could be identified from the TDEM data.

\section{Summary}

Presently (2008), a 16- $\mathrm{km}^{2}$ area of mainly rangeland in Bexar County, Texas, northeast of San Antonio is undergoing urban development. In Bexar County, residential and commercial development in much of the recharge zone is increasing. The karstic Edwards aquifer in the area could become contaminated by leakage of hazardous materials. In August 2007, the USGS, in cooperation with the San Antonio Water System, did a hydrogeologic and geophysical investigation to characterize the hydrostratigraphy (hydrostratigraphic zones) and also the hydrogeologic features (karst features such as sinkholes and caves) of the aquifer in the area being developed (study area). Hydrostratigraphic zones are subdivisions of the Edwards aquifer with distinct lithology, porosity, permeability, and hydrogeologic features. Knowledge of the hydrostratigraphy (and hydrogeologic features) can lead to better understanding of ground-water flow, and thus provide decision support for placement of monitoring wells for detecting contamination associated with urbanization.

Existing hydrostratigraphic information, enhanced by local-scale geologic mapping in the study area, and surface geophysics were used to associate ranges of electrical resistivities obtained from capacitively coupled (CC) resistivity surveys, frequency-domain electromagnetic (FDEM) surveys, time-domain electromagnetic (TDEM) soundings, and twodimensional direct-current (2D-DC) resistivity surveys with each of seven hydrostratigraphic zones (equivalent to members of the Kainer and Person Formations) of the Edwards aquifer. The TDEM soundings provide data for determining vertical resistivity variation, and the CC resistivity, FDEM, and 2D-DC resistivity surveys provide data for determining lateral resistivity variation.

The principal finding of this investigation is the relation between electrical resistivity and the contacts between the hydrostratigraphic zones of the Edwards aquifer and the underlying Trinity aquifer in the study area. However, TDEM data could not be used to delineate the various hydrostratigraphic zones of the Edwards aquifer continuously with depth because resistivities of each zone were not different enough to delineate differences in lithology. In general, the upper hydrostratigraphic zones (II through IV, Person Formation) of the aquifer have proportionately greater amounts of mudstone and wackestone than the lower hydrostratigraphic zones 
(V through VIII, Kainer Formation), rock types associated with relatively low resistivity/high relative conductivity (and relatively low permeability). The highest relative resistivity/ lowest relative conductivity (and highest relative permeability) is associated with crystalline limestone in hydrostratigraphic zone III (leached and collapsed members, undivided), VI (Kirschberg evaporite member), and VII (dolomitic member).

In general, the TDEM data indicate a two-layer model in which an electrical conductor underlies an electrical resistor, which is consistent with the Trinity aquifer (conductor) underlying the Edwards aquifer (resistor). Based on hydrostratigraphic zones identified from historical borehole log data, Bat Cave fault at one location is vertically displaced by about $30 \mathrm{~m}$. Based on TDEM soundings indicating the Edwards aquifer-Trinity aquifer contact, the displacement is about 60 $\mathrm{m}$, twice that from previously obtained borehole log data. TDEM data also show the Bat Cave fault plane to be associated with a local, nearly vertical zone of low resistivity that provides evidence, although not definitive, for Bat Cave fault functioning as a flow barrier, at least locally.

The CC resistivity, FDEM, and 2D-DC resistivity surveys provide sufficient data resolution for determining lateral resistivity variation and thus for estimating ranges of resistivity for each hydrostratigraphic zone of the Edwards aquifer. In general, the geophysical data show a sharp electrical contrast from north to south, changing from high resistivity to low resistivity across Bat Cave fault as well as possible karst features in the study area. Multiple continuous CC resistivity survey lines were collected that crossed previously mapped faults, and the same distinct high-to-low change close to the previously mapped location of Bat Cave fault is apparent in each line except one. Also, a CC resistivity-depth section shows a relatively large low-resistivity (high-conductivity) area between the two points at which the CC survey line crosses Bat Cave fault. This area is interpreted as possible karst (sinkholes) or intensely fractured rock in which the voids have been filled with clay and conductive soil.

A low-resistivity (high-conductivity) area observed in hydrostratigraphic zone III (leached and collapsed members, undivided) south of Bat Cave fault corresponds to a known sinkhole. Other potential karst areas-areas of low resistivity (high conductivity) - are apparent from the $\mathrm{CC}$ resistivity and FDEM data throughout the site.

Interpreted karst features that show relatively low resistivity within a relatively high-resistivity area likely are attributable to clays or soils filling a sinkhole. In general, faults are inferred where lithologic incongruity at the land surface indicates possible displacement. Along most inferred faults, displacement was not sufficient to place different members of the Kainer or Person Formations (hydrostratigraphic zones) adjacent across the inferred fault plane.

In general, the Kainer Formation (hydrostratigraphic zones V through VIII) has a higher resistivity than the Person Formation (hydrostratigraphic zones II through IV). Although resistivity variations from the CC resistivity, FDEM, and 2D-DC resistivity surveys, with mapping information, were sufficient to allow surface mapping of the lateral extent of hydrostratigraphic zones in places, resistivity variations from TDEM data were not sufficient to allow vertical delineation of hydrostratigraphic zones; however, the Edwards aquifer-Trinity aquifer contact could be identified from the TDEM data.

\section{Selected References}

Advanced Geosciences, Incorporated, 2007, Principles of geophysical methods for groundwater investigations: accessed September 1, 2007, at http://www.agiusa.com

American Society for Testing and Materials, 1999, Standard guide for using the direct current resistivity method for subsurface investigation: ASTM D 6431-99, 14 p.

American Society for Testing and Materials, 2001, Standard guide for conducting borehole geophysical logging-Electromagnetic induction: ASTM standard D 6726-01, 7 p.

American Society for Testing and Materials, 2004a, Standard guide for conducting borehole geophysical loggingGamma: ASTM D 6274-98, 11 p.

American Society for Testing and Materials, 2004b, Standard guide for conducting borehole geophysical loggingMechanical caliper: ASTM D 6167-97, 6 p.

American Society for Testing and Materials, 2004c, Standard guide for use of the metal detection method for subsurface investigation: ASTM D 7046-04, 7 p.

Ashworth, J.B., and Hopkins, Janie, 1995, Aquifers of Texas: Texas Water Development Board Report 345, 69 p.

Buszka, P.M., 1987, Relation of water chemistry of the Edwards aquifer to hydrogeology and land use, San Antonio region, Texas: U.S. Geological Survey Water-Resources Investigations Report 87-4116, $100 \mathrm{p}$.

Clark, A.K., 2003, Geologic framework and hydrogeologic features of the Glen Rose Limestone, Camp Bullis Training Site, Bexar County, Texas: U.S. Geological Survey WaterResources Investigations Report 03-4081, 9 p.

Clark, A.K., and Journey, C.A., 2006, Flow paths in the Edwards aquifer, northern Medina and northeastern Uvalde Counties, Texas, based on hydrologic identification and geochemical characterization and simulation: U.S. Geological Survey Scientific Investigations Report 2006-5200.

Constable, S.C., Parker, R.L., and Constable, C.G., 1987, Occam's inversion-A practical algorithm for generating smooth models from EM sounding data: Geophysics, v. 52, p. 289-300.

Dunham, R.J., 1962, Classification of carbonate rocks according to depositional texture, in Classification of Carbonate Rocks Symposium: American Association of Petroleum Geologists Memoir 1, p. 108-121. 
Fitterman, D.V., and Labson, V.F., 2005, Electromagnetic induction methods for environmental problems, in Butler, D.K., ed., Near-surface geophysics-Part 1, Concepts and fundamentals: Tulsa, Okla., Society of Exploration Geophysics, p. 295-349.

Geometrics, Inc., 2007, OhmMapper capacitively couple resis-

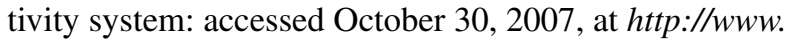
geometrics.com/OhmMapper/ohmmap.html

Geonics Ltd., 2005, Protem-57 transmitter: accessed November 1, 2007, at http://www.geonics.com/html/tem57-mk2. html

Geophex, Ltd., 2007, GEM-2 broadband EMI sensor: accessed October 30, 2007, at http://www.geophex.com/GEM-2/ GEM-2\%20home.htm

George, W.O., 1952, Geology and ground-water resources of Comal County, Texas, with sections on Surface-water runoff, by S.D. Breeding, and Chemical character of the water, by W.W. Hastings: U.S. Geological Survey Water-Supply Paper 1138, 126 p.

Geosoft Inc., 2007, Mapping and processing system help topics: Oasis montaj MAPS version 6.3.

Hanson, J.A., and Small, T.A., 1995, Geologic framework and hydrogeologic characteristics of the Edwards aquifer outcrop, Hays County, Texas: U.S. Geological Survey WaterResources Investigations Report 95-4265, 10 p.

Inman, J.R., 1975, Resistivity inversion with ridge regression: Journal of Geophysics v. 40, p. 798-817.

Interpex Ltd., 2007, IX1D v. 3 inversion software: accessed November 10, 2007, at http://www.interpex.com/ SoftwareIndex.htm

IRIS Instruments, 2006, Principles of geophysical methods for groundwater investigations: accessed August 30, 2006, at http://www.iris-instruments.com

Keller, G.V., and Frischknecht, F.C., 1966, Electrical methods in geophysical prospecting: London, Pergamon Press, $519 \mathrm{p}$.

Keys, W.S., 1990, Borehole geophysics applied to groundwater investigations: U.S. Geological Survey Techniques of Water-Resources Investigations, book 2, chap. E2, 150 p.

Kim, H.J., Song, Y., and Lee, K.H., 1997, High frequency electromagnetic inversion for the dispersive layered earth: Journal of Geomagnetism, Geoelectric 49, p. 1,439-1,450.

Kipp, G.K., Farrington, P.T., and Albach, M.J., 1993, Urban development on the Edwards aquifer recharge zone: Edwards Underground Water District Report 93-09, 40 p.

Kress, W.H., Ball, L.B., Teeple, A.P., and Turco, M.J., 2006, Two-dimensional direct-current resistivity survey to supplement borehole data in ground-water models of the former Blaine Naval Ammunition Depot, Hastings, Nebraska,
September 2003: U.S. Geological Survey Data Series 172, $37 \mathrm{p}$.

Loke, M.H., 2004, RES2DINV version 3.55-Rapid 2D resistivity and IP inversion using the least-squares methodGeoelectrical imaging 2-D and 3-D: Geotomo Software, 125 p., accessed July 12, 2007, at http://www.geoelectrical. com

Loke, M.H., Acworth, Ian, and Dahlin, Torleif, 2003, A comparison of smooth and blocky inversion methods in 2D electrical imaging surveys: Exploration Geophysics, v. 34, p. $182-187$.

Lucius, J.E., Langer, W.H., and Ellefsen, K.J., 2007, An introduction to using surface geophysics to characterize sand and gravel deposits: U.S. Geological Survey Circular 1310, $33 \mathrm{p}$.

Maclay, R.W., 1995, Geology and hydrology of the Edwards aquifer in the San Antonio area, Texas: U.S. Geological Survey Water-Resources Investigations Report 95-4186, 64 p., 12 pl.

Maclay, R.W., and Small, T.A., 1976, Progress report on geology of the Edwards aquifer, San Antonio area, Texas, and preliminary interpretation of borehole geophysical and laboratory data on carbonate rocks: U.S. Geological Survey Open-File Report 76-627, 65 p.

Monash GeoScope, 2007, terraTEM operations manual: revision 3.0, August 2006, 87 p.

Morrison, F., Gasperikova, E., and Washbourne, J., 2004, The Berkeley course in applied geophysics-Chapter 4, DC electric methods: accessed September 19, 2008, at http://appliedgeophysics.berkeley.edu:7057/.

Rose, P.R., 1972, Edwards Group, surface and subsurface, central Texas: Austin, University of Texas, Bureau of Economic Geology Report of Investigations 74, 198 p.

Smith, B.D., Irvine, R., Blome, C.D., Clark, A.K., and Smith, D.V., 2003, Preliminary results, helicopter electromagnetic and magnetic survey of the Seco Creek Area, Medina and Uvalde Counties, Texas: Proceedings, Symposium on the Application of Geophysics to Environmental and Engineering Problems, San Antonio, Tex., 13 p.

Smith, B. D., Blome, C.D., Clark, A. C., Kress, W., and Smith, D.V., 2007, Using geophysics to define hydrostratigraphic units in the Edwards and Trinity aquifers, Texas: Proceedings, American Geophysical Union Spring Meeting 2007, $1 \mathrm{p}$.

Stanton, G.P., Kress, W.H., Teeple, A.P., Greenslate, M.L., and Clark, A.K., 2007, Geophysical analysis of the Salmon Peak Formation near Amistad Reservoir dam, Val Verde County, Texas, and Coahuila, Mexico, March 2006, to aid in piezometer placement: U.S. Geological Survey Scientific Investigations Report 2007-5143, 72 p. 
Stein, W.G., and Ozuna, G.B., 1995, Geologic framework and hydrogeologic characteristics of the Edwards aquifer recharge zone, Bexar County, Texas: U.S. Geological Survey Water-Resources Investigations Report 95-4030, 8 p.

U.S. Army Corps of Engineers, 1995, Geophysical exploration for engineering and environmental investigations: Engineering Manual 1110-1-1802, chap. 4, 57 p.

Veni, George, 1988, The caves of Bexar County (2d ed.): Austin, Tex., University of Texas, Texas Memorial Museum Speleological Society Bulletin, v. 10, p. 199-213.
Won, T., Choi, C.H., and Im, G.H., 2006, Single carrier frequency-domain equalization with transmit diversity over mobile multipath channels: accessed August 30, 2007, at http://ietcom.oxfordjournals.org/cgi/content/refs/ E89-B/7/2050

Zohdy, A.A., Eaton, G.P., and Mabey, D.R., 1974, Application of surface geophysics to ground-water investigations: U.S. Geological Survey Techniques of Water-Resources Investigations, book 2, chap. D1, $116 \mathrm{p}$. 
Blank Page 


\section{Appendix 1-Datasets of Raw and Processed Data for All Geophysical Methods}


Blank Page 


\section{Datasets of Raw and Processed Data for All Geophysical Methods}

Readme.txt

\section{Capacitively Coupled Resistivity (CC_resistivity)}

Raw-Includes all .bin files downloaded directly from the OhmMapper TR5 obtained during data collection, as well as .stn files converted from .bin files. These files can be imported into a filtering program. Link to CC_res_Raw.zip files.

Processed-Includes the .dat files exported from the AGI EarthImager 2-D inversion software after the inversion process. These files include all final inversion data for each line collected at the site. Link to CC_res_Processed.zip files.

\section{Frequency-Domain Electromagnetics (FDEM)}

Raw-Includes two separate .csv files: one for the data collected along a profile and one for global positioning system (GPS) coordinates for each day a FDEM profile was collected. These files contain in-phase and quadrature data at each frequency. Link to FDEM_Raw.zip files.

Processed-Includes all .gem files (binary format) directly downloaded from the GEM-2 and .gdf database files that can be opened in Oasis montaj. The .gem files are converted to .csv files and then subsequently imported into Oasis montaj for analysis. The .gbf files were created using the Oasis montaj Helicopter Electromagnetic (HEM) module, which was used to filter data and calculate apparent resistivity of the quadrature data at each frequency for every GEM-2 profile line. Link to FDEM_Processed.zip files.

\section{Time-Domain Electromagnetic Soundings (TDEM)}

\section{Protem}

Raw-Includes all .red files generated from the Protem 47 and 57. A .red file consists of multiple soundings containing information for each duty cycle collected by the Protem 47 and 57. Link to Protem_Raw.zip files.

Processed-Includes all .mdl or model files (ASCII format) of the TDEM layered-earth models. Also included for each sounding is the .usf file that can be imported into IX1D as raw data.Link to Protem_Processed.zip files.

\section{TerraTEM}

Raw-Includes all .bin files downloaded directly from the terraTEM data collection unit. Three .bin files that represent the high and intermediate resolution duty cycles, as well as a noise measurement .bin file, are created for each sounding. Link to TerraTEM_Raw.zip files.

Processed-Includes all .mdl files (ASCII format) of the TDEM layered-earth models. Also included for each sounding is the .usf file that can be imported into multiple inversion programs including IX1D. Link to TerraTEM_Processed.zip files. 


\section{Direct-Current Resistivity (DC_Resistivity)}

Raw-Includes all .csv and .bin files for each line for both the dipole-dipole and hybrid Wenner-Schlumberger arrays output from the IRIS Instruments Syscal Pro system. Line 1 is split into two parts: the north (N) and south (S) sides of the line. Line 2 is split into the east and west sides of the 2D-DC resistivity line. Link to DC_res_Raw.zip files.

Processed-Includes all .dat and inv files for both the dipole-dipole and hybrid Wenner-Schlumberger arrays. The .dat files are inversion results exported from the AGI EarthImager 2-D inversion software and .inv files are exported from RES2DINV. Link to DC_res_Processed.zip files.

Publishing support provided by

Lafayette Publishing Service Center

Information regarding water resources in Texas is available at

http://tx.usgs.gov/ 